\title{
EFEITOS DE FATORES GENÉTICOS E DO SISTEMA DE CRIAÇÃO SOBRE O DESEMPENHO E O RENDIMENTO DE CARCAÇA DE FRANGOS TIPO CAIPIRA
}

\author{
PAULO HELLMEISTER FILHO
}

Tese apresentada à Escola Superior de Agricultura "Luiz de Queiroz", Universidade de São Paulo, para obtenção do título de Doutor em Agronomia, Área de Concentração: Ciência Animal e Pastagens.

P I R A C I C A B A

Estado de São Paulo - Brasil

Outubro - 2002 


\title{
EFEITOS DE FATORES GENÉTICOS E DO SISTEMA DE CRIAÇÃO SOBRE O DESEMPENHO E O RENDIMENTO DE CARCAÇA DE FRANGOS TIPO CAIPIRA
}

\author{
PAULO HELLMEISTER FILHO
}

Médico Veterinário

\section{Orientador: Prof. Dr. JOSÉ FERNANDO MACHADO MENTEN}

\begin{abstract}
Tese apresentada à Escola Superior de Agricultura "Luiz de Queiroz", Universidade de São Paulo, para obtenção do título de Doutor em Agronomia, Área de Concentração: Ciência Animal e Pastagens.
\end{abstract}

P I R A C I C A B A

Estado de São Paulo - Brasil

Outubro - 2002 


\section{Dados Internacionais de Catalogação na Publicação (CIP)} DIVISÃO DE BIBLIOTECA E DOCUMENTAÇÃO - ESALQ/USP

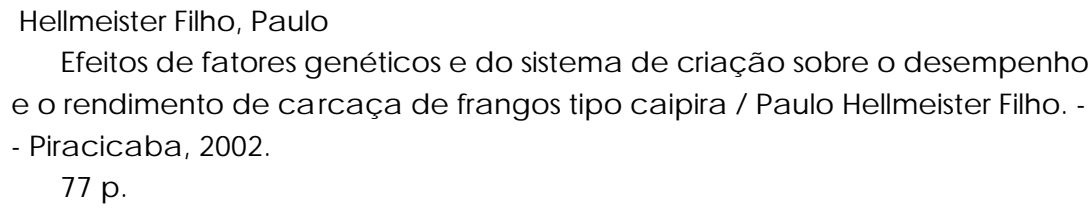

Tese (doutorado) - Escola Superior de Agricultura Luiz de Queiroz, 2002. Bibliografia.

1. Carcaça - rendimento 2. Frangos de corte caipira 3. Sistema de criação a nimal I. Título

CDD 636.513

\section{"Permitida a cópia total ou parcial deste documento, desde que citada a fonte - $O$ autor"}


Dedico

Á minha companheira Antonia Marlene e ao meu filho Vítor, pelo amor e carinho recebido.

\section{Ofereço}

Aos meus pais Paulo e Zilda, por quem tenho muito amor e gratidão. Á minha irmã, meu cunhado e meus sobrinhos, pelo apoio e carinho. 


\section{AGRADECIMENTOS}

Á DEUS, pela alegria de viver.

Ao Prof. Dr. José Fernando Machado Menten pela amizade, compreensão e pela orientação na execução deste trabalho.

Aos Prof. Dr. Antônio Augusto Domingos Coelho e Prof. Dr. Vicente José Maria Savino pela amizade, apoio e incentivo dedicados à realização de todas as atividades.

Ao Prof. Dr. Ariel Antonio Mendes da UNESP-Botucatu pelo apoio na realização dos abates experimentais.

Á Universidade Estadual de Santa Cruz - UESC - pelo incentivo e valorização à minha formação profissional.

Ao professor Dr. Antonio Augusto Franco Garcia pelo assessoramento nas análises estatísticas.

Á todos os professores do Departamento de Zootecnia pelos ensinamentos durante o curso de doutorado. 
Ao grande amigo Marco Aurélio Neves da Silva pela indispensável colaboração e dedicação em todos os momentos do trabalho.

Aos amigos Marco, Millor, Edmilson, Edival, Nuir, Lico, Sidney, Rafael, Carmo e Carlos Macedônio, todos do eterno setor de aves.

Aos amigos Norberto, César, Sérgio, Natálio, Berdan e a todos os demais amigos e funcionários do Departamento de Genética pelo sempre pronto apoio prestado.

Aos amigos Aline, Adriana, Cláudia de Paz, Cláudia Chuahy, Vera Lucia, Creide Ely, Flávio, José Henrique, José Otávio e Juliano pela amizade e colaboração durante o curso de doutorado.

Aos amigos da UNESP- Botucatu, Rodrigo e Joerley pela grande ajuda em todos os abates realizados.

Aos funcionários do Departamento de Zootecnia, especialmente Alexandre, Ednésio, Filó, Leonilson e Bonato pela indispensável colaboração na condução dos trabalhos.

Á todos os funcionários da Biblioteca Central, em especial às bibliotecárias Eliana M. Garcia e Sílvia Maria Zinsly pela ajuda, atenção e esclarecimentos prestados.

Á todos os funcionários da Pós Graduação Central pelo total apoio.

Aos funcionários do abatedouro experimental da UNESP-Botucatu.

A todos que de alguma maneira me ajudaram a realizar este trabalho. 


\section{SUMÁRIO}

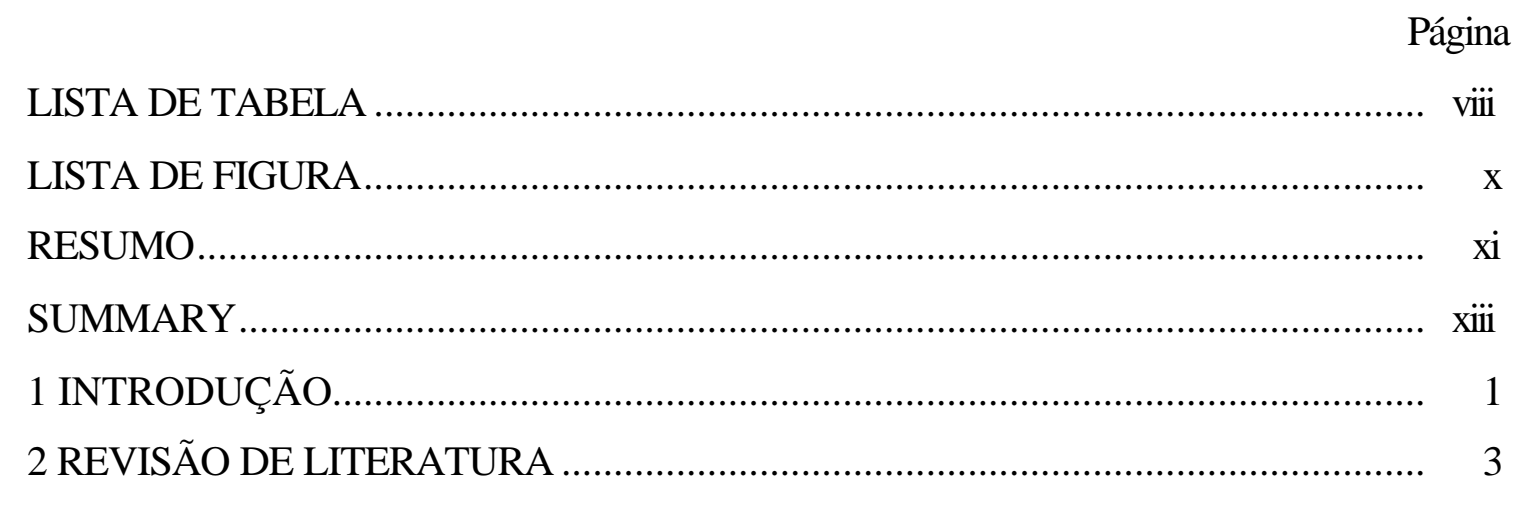

2.1 Sistema alternativo de criação de frangos ........................................................... 3

2.2 Fatores genéticos e de meio que atuam no desempenho de frangos de corte ............. 9

2.3 Rendimento de carcaça ............................................................................... 13

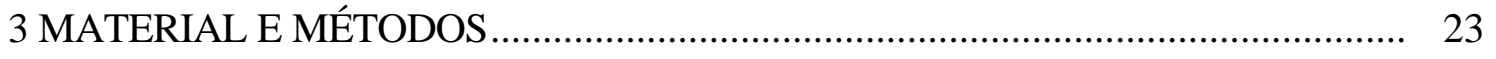

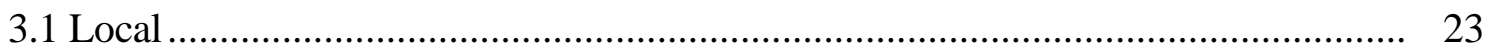

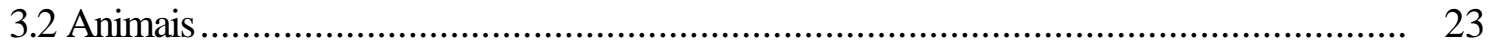

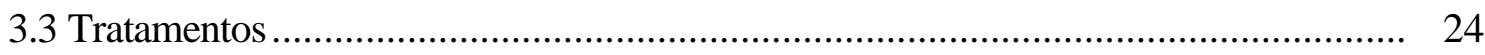

3.4 Instalações, preparação e condução do experimento............................................ 24

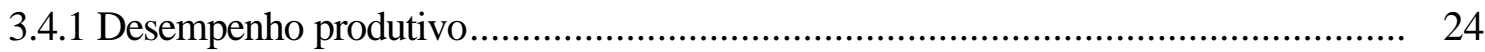

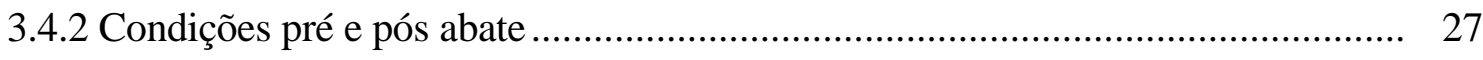

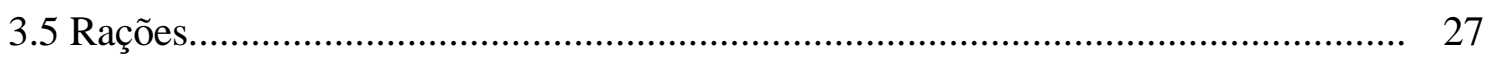

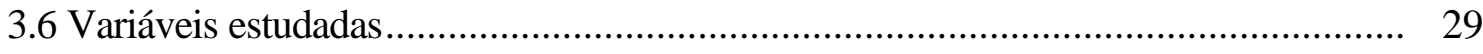

3.6.1 Idade das aves ao atingir o peso de 2300g (Idade 2300) .................................. 29

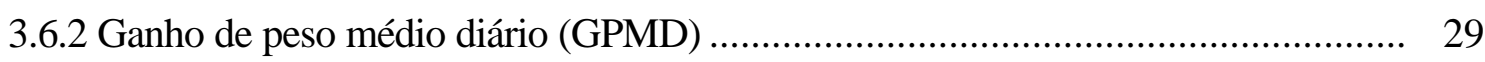

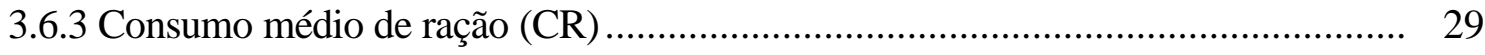

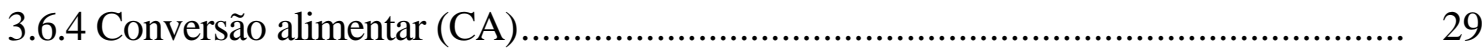




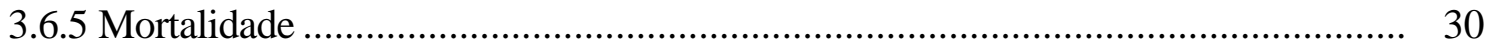

3.6.6 Rendimento das partes principais da carcaça....................................................... $\quad 30$

3.6.7 Rendimento das partes secundárias da carcaça ..................................................... 30

3.7 Delineamento experimental e análise estatística.................................................... 30

4 RESULTADOS E DISCUSSÃO ................................................................ 32

4.1 Desempenho produtivo................................................................................ 32

4.1.1 Efeito da linhagem ............................................................................... 33

4.1.2 Efeito do sistema de criação ........................................................................... 36

4.1.3 Linhagem e sistema de criação............................................................................. 37

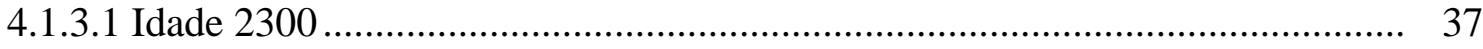

4.1.3.2 Ganho de peso médio diário (GPMD) ……..................................................... 39

4.1.3.3 Consumo de ração (CR) ........................................................................... 41

4.1.3.4 Conversão alimentar (CA) ..................................................................... 41

4.2 Rendimento de carcaça ..................................................................................... 42

4.2.1 Rendimento das partes principais da carcaça.......................................................... 46

4.2.1.1 Efeito da linhagem ................................................................................... 46

4.2.1.2 Efeito do sistema de criação ....................................................................... 48

4.2.1.3 Efeito do sexo …................................................................................. 50

4.2.1.4 Linhagem e sistema de criação ......................................................................... 51

4.2.1.5 Linhagem e sexo............................................................................. 54

4.2.2 Rendimento das partes secundárias da carcaça …................................................ 56

4.2.2.1 Efeito de linhagem .................................................................................. 56

4.2.2.2 Efeito do sistema de criação .......................................................................... 58

4.2.2.2 Efeito do sexo …................................................................................. 60

4.2.2.4 Linhagem e sistema de criação ......................................................................... 62

4.2.2.5 Linhagem e sexo.......................................................................................... 64

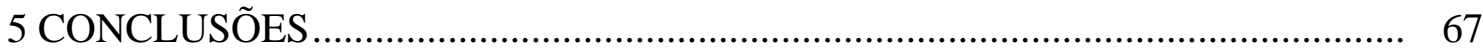

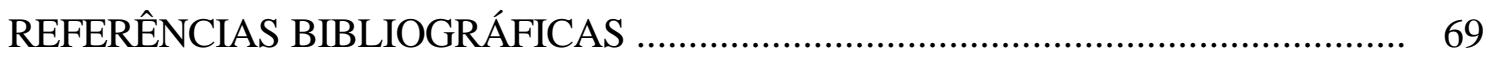




\section{LISTA DE TABELAS}

Página

1 Composição percentual e valores calculados das rações...................................... 28

2 Análise de variância das variáveis estudadas...................................................... 33

3 Médias das linhagens para as variáveis idade aos 2300g (Idade 2300), ganho de peso médio diário (GPMD), consumo de ração (CR), conversão alimentar (CA) e mortalidade. 36

4 Médias dos sistemas intensivo e semi-intensivo de criação para as variáveis idade aos 2300g (Idade 2300), ganho de peso médio diário (GPMD), consumo de ração (CR), conversão alimentar (CA)

e mortalidade.

5 Média das linhagens para as características idade 2300, ganho de peso médio diário (GPMD), consumo de ração (CR), conversão alimentar (CA) e mortalidade (Mort.), nos diferentes sistemas de criação. ..................................... 39

6 Análise de variância das variáveis das carcaças estudadas.................................. 43

7 Análise de variância das variáveis das carcaças estudadas.................................... 44

8 Análise de variância das variáveis das carcaças estudadas.................................... 45

9 Comparação entre médias das linhagens Label Rouge (LR), Caipirinha (CP), 7P e Paraíso Pedrês (PP), para as variáveis rendimento das partes principais da carcaça.................................................... 48

10 Comparação entre médias das linhagens Label Rouge (LR), Caipirinha (CP), 7P e Paraíso Pedrês (PP), para as variáveis de rendimento das partes principais da carcaça, nos sistemas intensivo (I) e semi intensivo (SI) de criação de criação 
11 Comparação entre médias das linhagens Label Rouge (LR), Caipirinha (CP), 7P e Paraíso Pedrês (PP), para as variáveis de rendimento das partes principais da carcaça, nos diferentes sexos.......................... 51

12 Comparação entre médias das linhagens Label Rouge (LR), Caipirinha (CP), 7P e Paraíso Pedrês (PP), para as variáveis de rendimento das partes secundárias da carcaça................................................... 58

13 Comparação entre médias das linhagens Label Rouge (LR), Caipirinha (CP), 7P e Paraíso Pedrês (PP), para as variáveis de rendimento das partes secundárias da carcaça, nos sistemas intensivo (I) e semi intensivo (SI) de criação de criação.

14 Comparação entre médias das linhagens Label Rouge (LR), Caipirinha (CP), 7P e Paraíso Pedrês (PP), para as variáveis rendimento das partes secundárias da carcaça, nos diferentes sexos. 


\section{LISTA DE FIGURAS}

Página

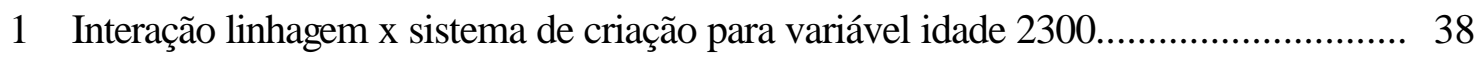

2 Interação linhagem x sistema de criação para variável ganho de peso médio diário 40

3 Interação linhagem x sistema de criação para variável rendimento de carne ................ 53

4 Interação linhagem x sexo para variável percentagem de asa................................. 54

5 Interação linhagem x sexo para variável percentagem de pés ............................... 64 


\title{
EFEITOS DE FATORES GENÉTICOS E DO SISTEMA DE CRIAÇÃO SOBRE O DESEMPENHO E O RENDIMENTO DE CARCAÇA DE FRANGOS TIPO CAIPIRA
}

\author{
Autor: PAULO HELLMEISTER FILHO \\ Orientador: Prof. Dr. JOSÉ FERNANDO MACHADO MENTEN
}

\section{RESUMO}

O experimento teve por objetivo verificar os efeitos de fatores genéticos e do sistema de criação sobre o desempenho e o rendimento de carcaça de frangos tipo caipira. Foram utilizados 1120 pintos de um dia provenientes de ovos férteis de quatro linhagens alternativas de frango de corte tipo caipira, sendo duas comerciais e duas experimentais, desenvolvidas no Departamento de Genética da ESALQ/USP. Foi empregado o delineamento experimental em faixas com oito tratamentos, quatro repetições e 35 aves por unidade experimental. As linhagens foram: Comercial Label Rouge (crescimento lento), Comercial Paraíso Pedrês (crescimento rápido), Experimental Caipirinha (crescimento lento), Experimental 7P (crescimento rápido). As variáveis estudadas foram: idade das aves ao atingir o peso de 2300g (Idade 2300), ganho de peso médio diário (GPMD), consumo médio de ração (CR), conversão alimentar (CA), mortalidade, rendimento das partes principais da carcaça (carcaça eviscerada, pernas, asa, peito, dorso, carne de perna e carne de peito) e rendimento das partes secundárias da carcaça (osso de perna, osso de perna, pele de perna, pele de coxa, gordura abdominal, vísceras, pés e cabeça + pescoço). Os tratamentos experimentais consistiram de quatro linhagens caipiras criadas nos sistemas intensivo e semi-intensivo, 
sendo que no sistema intensivo de criação as aves ficaram confinadas no galpão durante todo o tratamento e no sistema semi-intensivo o acesso livre ao pasto ocorreu depois dos 21 dias de idade. Quando os tratamentos atingiam o peso médio $2300 \mathrm{~g}$, os dados de desempenho foram avaliados e foram escolhidas 24 aves por linhagem (12 machos e 12 fêmeas), para abate após um período de jejum de 8 horas. Foram detectados efeitos significativos nos valores de Idade 2300 e GPMD nas comparações entre linhagens, sistema de criação e interação linhagem x sistema de criação. Diferenças significativas de CR e CA foram observadas apenas nas comparações entre linhagens. A mortalidade não foi significativa em nenhuma das variáveis estudadas. Foram observadas diferenças significativas entre as linhagens para as variáveis asa, carne de peito, osso de perna, osso de peito e pele de peito, gordura abdominal. Em relação aos sistemas de criação, foram observadas diferenças significativas para dorso. Em relação ao sexo, foram encontradas diferenças significativas para pernas, asa, peito, carne de pernas e de peito, osso das pernas, pele de peito, gordura abdominal, vísceras e pés. Apenas carne de peito teve efeito da interação linhagem x sistema de criação, enquanto asa e pés sofreram interação linhagem $\mathrm{x}$ sexo. $\mathrm{O}$ acesso à pastagem no sistema semi-intensivo não representou economia de ração ou melhora na conversão alimentar, mas resultou em redução no ganho diário de peso (reflexo do consumo diário de ração) da linhagem Caipirinha, provavelmente em razão de sua maior permanência no piquete. 


\title{
EFFECT OF GENETIC FACTORS AND REARING SYSTEM ON THE PERFORMANCE AND CARCASS YIELD OF FREE RANGE BROILER CHICKENS
}

\author{
Author: PAULO HELLMEISTER FILHO \\ Adviser: Prof. Dr. JOSÉ FERNANDO MACHADO MENTEN
}

\section{SUMMARY}

The objective of this trial was verify the effect of genetic factors and rearing system on the performance and carcass yield of free range broiler chickens. Eleven hundred and twenty day-old chicks hatched in the same conditions from four different broiler chicken strains (two commercial strains and two strains developed in the Department of Genetics of the ESALQ/USP) were used. The experiment consisted of eight treatments, four replicates and 35 birds per experimental unit. The strains were commercial Label Rouge (low growth), commercial Paraiso Pedrês (high growth), experimental Free Range (low growth), experimental 7P (high growth). The chickens wee housed in floor pens and those on the free-range treatment had access to a pasture area after 21 day of age. The variable analyzed were: age of the birds to achieve the weight of 2300g (Age 2300), average daily weight gain (ADWG), average feed consumption (AFC), feed conversion (FC), mortality, main parts of carcass yield (eviscerate carcass, leg, wing, breast, back, meat of leg and meat of breast) and secondary carcass yield (bone of chest, bone of leg, skin of breast, skin of drumstick, abdominal fat pad, viscera, feet and head + neck). When the treatments reached average 
weight $2300 \mathrm{~g}$, the performance data were evaluated and 24 birds per strain (12 males and 12 females), were sacrificed for carcass evaluation. The results detected significant differences in the values of age 2300 and ADWG in the comparisons between strains, rearing system and interaction strain $\mathrm{x}$ rearing system. Significant differences of AFC and FC were observed only in the comparisons among strain. Mortality was not affected by treatments. Significant differences between the strains had been observed for the variables wing, meat of breast, bone of leg, bone of chest and skin of chest, abdominal fat pad. In relation to the rearing systems, significant differences were observed only for the back. For sex, had been found significant differences for legs, wing, breast, meat of legs and breast, bone of the legs, skin of breast, abdominal fat, viscera and feet. However, the interaction strain $\mathrm{x}$ rearing system affected significantly breast meat and the interaction strain $\mathrm{x}$ sex affected significantly wing and feet. The access to pasture in the semi-intensive system did not result in feed economy or improvement in the feed conversion, but resulted in reduction in the daily weight gain (as a consequence of daily feed intake) in the Caipirinha, probably because the birds stayed for a longer period of time in the pasture area 


\section{INTRODUÇÃO}

A avicultura no Brasil é uma das atividades que mais tem se desenvolvido. Este progresso, tanto em número de frangos abatidos como no de ovos produzidos, possibilitou a indústria avícola um notável potencial para prover aos consumidores fontes protéicas saudáveis e a um custo baixo.

Com os constantes avanços tecnológicos obtidos e a utilização de aves altamente especializadas com grande potencial genético direcionado para o crescimento e demais índices zootécnicos de interesse, a avicultura brasileira apresenta alta eficiência e volume de produção. Além disso, constantes pesquisas no campo da nutrição e manejo têm contribuído para o aumento do peso de abate, melhoria na eficiência alimentar, diminuição de tempo para o abate com excelente qualidade e rendimento de carcaça.

A expansão do sistema intensivo de criação de frangos de corte, juntamente com o aumento de número de aves por metro quadrado, proporciona uma otimização da produção por área. Em contrapartida, este regime de total confinamento gera um ambiente desfavorável ao bem estar das aves que pode promover o declínio nos índices produtivos. Recentemente, porém, a criação dessas aves em sistemas alternativos tem sido desenvolvido por alguns produtores que buscam eficiência e qualidade de produção em um sistema diferenciado. Os objetivos destes criadores são diminuir os custos de produção e utilizar um sistema de criação mais natural para poder agregar valor a um produto diferenciado, tendo em vista a procura de consumidores por produtos alternativos e de melhor qualidade. Esses produtores buscam também a melhoria dos índices zootécnicos da criação dentro do sistema alternativo, também conhecido como semi-intensivo ou "sistema caipira". 
Hoje, sabe-se que para que ocorra o aumento da produtividade do sistema semi-intensivo, não basta o oferecimento de condições ambientais adequadas para as aves; é também necessária, a utilização de aves melhoradas e adaptadas para o sistema alternativo, com alto potencial genético, além de condições adequadas de manejo e nutrição para o sistema.

A definição clara do papel do sistema alternativo de criação será o ponto de partida que permitirá a avaliação e o desenvolvimento de materiais genéticos especializados para esse sistema.

Estudos envolvendo a associação entre sistemas de criação de frango caipira são praticamente inexistentes.

Portanto, o objetivo principal do presente trabalho foi o de verificar o efeito da linhagem, ambiente e sexo no desempenho zootécnico, rendimento de carcaça e qualidade de carne de frangos de corte caipira melhorado. 


\section{REVISÃO DE LITERATURA}

\subsection{Sistema alternativo de criação de frangos}

Antes de iniciar uma revisão sobre "Sistema Alternativo de Criação de Frangos de Corte" se faz necessário realizar uma pequena recapitulação de como a "Avicultura" chegou aos dias de hoje.

A galinha teve sua origem cerca de 150 milhões de anos arás, a partir do Archaeopterix que teria tido seu habitat na região hoje conhecida como a Índia. Desta ave foram identificados 3 espécimens, sendo que da Ave Vermelha da Floresta (Gallus bankiva), surgiriam as aves de hoje (Gallus gallus).

A domesticação das aves teve origem por volta dos anos $3200 \mathrm{aC}$ e com duas finalidades principais: adorno e briga. Porém, os indivíduos que não serviam mais para estes fins eram então abatidos para o consumo.

No século XVI as brigas de galos eram muito difundidas na Europa e os criadores muito exigentes em relação às características de força e agressão das aves. Por volta de meados do século XIX as brigas foram proibidas e, como conseqüência, surgiram as exposições com objetivo de eleger as aves mais belas em relação à plumagem, tamanho corporal, formato de cristas e barbelas. Portanto, pode-se dizer que nascia o interesse pela exploração das aves e o início dos primeiros passos rumo ao desenvolvimento da produção avícola mundial.

Após ampla revisão histórica sobre as origens da galinha caipira no Brasil, Gessulli (1999) relata que existem fortes indícios, apresentados pelo historiador Martin Bueno de Mesquita, que a galinha foi introduzida muitos anos antes do descobrimento, através dos corsários franceses. Embora não confirmada a hipótese, o 
autor afirma que a avicultura caipira tem mais de 500 anos, pois na certidão de nascimento do Brasil, representada pela carta enviada ao rei de Portugal, Dom Manuel, lavrada por Pero Vaz de Caminha, escrivão de Pedro Alvares Cabral, a galinha figurou como um dos primeiros animais domésticos que chegaram às terras brasileiras recém descobertas.

Continuando com a história da avicultura brasileira, Silva \& Nakano (1997) apresentam que entre os anos de 1900 a 1930 a avicultura passou por um período chamado "Colonial", em que as aves eram criadas totalmente soltas e sem nenhum critério específico de produção. Entre os anos de 1930 a 1940 surgiu o período "Romântico" e as características de beleza em relação as variadas cores das penas, tamanho da ave, forma das cristas e barbelas, passaram a ser selecionadas e disputadas pelos criadores. Durante os anos de 1940 a 1960, em plena época de escassez de alimentos provocada pela segunda guerra mundial, iniciou-se o período das "Aptidões Mistas", onde as aves para produção de carne e ovos passaram a ser criadas no sistema de parques com acesso livre às áreas de pasto e também dentro do galpão. Entre os anos de 1960 a 1970 surgiu o período de "Especialização das Raças" e as aves passaram a ser criadas dentro do galpão surgindo, portanto, o sistema confinado. Durante os anos de 1970 a 1975 deu-se origem ao período "Super Industrial" onde as linhagens comerciais, no sistema confinado, passaram a dominar o mercado com excelentes resultados de produção. Entre os anos de 1975 a 1988 surgiu o período de "Exportação" em que o frango inteiro foi o principal produto e, a partir de 1988, com as mudanças das exigências no mercado consumidor nacional e internacional, deu-se inicio ao período de "Processamento", onde os mais variados tipos de cortes e de produtos de frangos tomaram conta do mercado.

Nos dias de hoje, o sistema confinado, também conhecido como "sistema intensivo de criação de frangos de corte", apresenta excelentes resultados de produção, de rendimento e preços acessíveis ao consumidor, porém, recentemente, o sistema semiintensivo de criação de aves está chamando a atenção para novas pesquisas devido a crescente demanda. 
A pressão dos mercados consumidores, primeiramente da Europa e, mais recentemente de todos os países emergentes, por alimentos mais saudáveis, com menores concentrações de resíduos químicos, fez com que o modelo tradicional de produção de frangos de corte fosse repensado em determinados aspectos. Também, a relação do bem estar dos animais produtores de alimentos está sendo questionada, assim como a questão da poluição ambiental pelos dejetos produzidos por estes animais (Bolis, 2001). Na França, o mercado de produtos naturais, orgânicos e alternativos tem se tornado mais expressivo ano após ano, tendo aproximadamente 11 diferentes tipos de frangos, produzidos e classificados de acordo com o modo de produção, região, país de origem, linhagens utilizadas, alimentação ou selos de garantia de qualidade.

Segundo Figueiredo (2001), a alta competitividade entre as empresas e o aumento da produção intensiva de frangos de corte fizeram surgir movimentos sociais e grupos de consumidores preocupados com o bem estar das aves e com os ingredientes utilizados nas rações. Tais movimentos estão incentivando cada vez mais o consumo de produtos artesanais e com rastreabilidade, tornando crescente a demanda por frangos criados de forma menos intensiva, denominados de produção alternativa. Segundo De Barba ${ }^{1}$ citado por Figueiredo (2001), a partir de 1924 surgiram, no mundo, movimentos que valorizaram o uso de matéria prima orgânica e tratavam o solo como um ser vivo e não como um corpo inerte. Os movimentos evoluíram tornaram-se conhecidos como escolas de agricultura alternativas e compartilharam suas bases técnicas e orientações ecológicas.

Ciocca et al. (1995) relata que, até a década de 60, a produção de ovos e carne de galinha em todo o Brasil se originava de sistemas de criação semi-intensivo. Esse modo de produção passou a perder importância a partir da importação de animais melhorados geneticamente, de alto potencial de produção, e da subsequente implantação

De BARBA, J.F. Agricultura alternativa. Histórico e filosofias. In: Curso profissionalizante de agroecologia. EPAGRI. Ituporanga, SC. 2000. 
da avicultura industrial no país, que ocupou o mercado avícola. Embora com espaço comercial reduzido e relegados a segundo plano quanto à atenção técnica, esses sistemas de produção persistiram no meio rural, mantidos predominantemente em criações destinadas à produção de subsistência.

Com relação aos diferentes tipos de criação de aves no sistema de subsistência, Ciocca (1995) afirma que, no primeiro deles, os animais são criados soltos, não havendo construções nem equipamentos, nem fornecimento regular de alimentos. A única operação sistemática é a coleta de ovos ou aves, mas não é conhecido o nível de produção. Com relação ao segundo sistema, são encontrados alojamentos e equipamentos, parte da alimentação é fornecida, havendo também interferências na reprodução, época e eventual escolha dos reprodutores. A coleta de produtos torna-se organizada, já que o extravio de produto é minimizado, permitindo quantificar a produção. Os animais encontrados nesses sistemas são, em expressiva maioria, aves sem raças definidas (SRD), encontrando-se, em menor número, gerações comerciais de aves desenvolvidas pela indústria avícola e, em algumas regiões, encontram-se também pequenas criações de raças, bem como algumas linhagens e/ou cruzamentos.

Gessulli (1999), relata que falar sobre o "Sistema de Criação de Galinhas Caipira " é oportuno e necessário, devido à falta de informações existentes no mercado para os atuais e futuros criadores e que, apesar da grande dimensão de terras no Brasil, somada ao grande número de pequenas propriedades e a tradição na criação de galinhas caipiras, nos encontramos totalmente desatualizados ha mais de 30 anos, fruto da introdução da avicultura industrial e da degeneração das aves tradicionais caipiras.

Silva \& Nakano (1997) afirmam que, até a década de 40, havia relativamente bastante informações sobre o sistema semi-intensivo de criação de aves, tais como, pastagens, castração de frangos, seleção fenotípica para produção de ovos, entre outras e que, após o advento da avicultura industrial, esses assuntos caíram totalmente em desuso.

No Brasil, com relação ao desenvolvimento e criação de frangos alternativos, temos uma pequena demanda de mercado por frangos caipiras ou colonial e outra demanda por frangos orgânicos ou livres de antibióticos. Em relação ao mercado 
exterior, temos também uma pequena fatia onde os frangos passam a ser criados dentro de exigências ou normas estabelecidas muitas vezes, pelo próprio cliente comprador do frango.

Com objetivo de regulamentar os sistemas alternativos de criação de aves, o Ministério da Agricultura e do Abastecimento estabeleceu normas para o sistema de produção de frangos coloniais/caipira que estão descritas no Oficio Circular DOI/DIPOA n ${ }^{\text {o }}$ 007/99 de 19.05.1999. Com relação ao sistema de produção de ovos coloniais/caipira, as normas estão descritas no Oficio Circular DOI/DIPOA no 008/99 de 19.05.1999, que obedece a norma do ovo (Normas gerais de inspeção de ovos e derivados - Portaria SIPA 001/90 de 21/02/90).

O sistema de produção de aves orgânica/agroecológica também foi regulamentado pelo Ministério da Agricultura e do Abastecimento através da Portaria $\mathrm{N}^{\circ}$ 505, de 16 de outubro de 1998.

Segundo Figueiredo et al. (2001), tecnicamente podem ser considerados sinônimos os termos sistema orgânico, ecológico, biológico, biodinâmico, natural, sustentável, regenerativo e agroecológico, assim como, também podem ser considerados sinônimos de Frango Caipira, Frango Colonial, Frango Tipo Caipira, Frango Estilo Caipira, Frango Tipo Colonial, Frango Estilo Colonial e Frango Verde. Entretanto, devese levar em consideração a relação entre os termos regionais de uso mais restrito, como é o caso do Frango da Roça, Frango de Capoeira, Galinha Pé Duro, Galinha Nativa e Frango Índio que podem ser considerados sinônimos sob a denominação de galinhas nativas.

Naas et al. (2001) relatam em uma revisão que a situação da qualidade do ar dentro e imediatamente fora das granjas de frango de corte tem relação direta com à salubridade e agressão ao meio ambiente externo. Com objetivo de otimizar a produção industrial de carne, o sistema intensivo de produção tem aumentado a densidade de criação de frangos, o que gera alterações dentro do ambiente, tanto do ponto de vista termodinâmico, quanto da qualidade do ar presente, colocando em risco os aspectos sanitários, econômicos, de biosseguridade e bem estar animal. Entretanto, o sistema semi-intensivo, que corresponde à produção do frango alternativo, ou minimamente 
abrigado, repensa os conceitos já utilizados e se insere dentro do grande movimento internacional que tende a buscar alternativas de produção menos agressivas ao ambiente do planeta como um todo e aos indivíduos em particular.

Quando as aves são criadas no sistema semi-intensivo, a quantidade de esterco é menor dentro do galpão, gerando, portanto, menor possibilidade de degradação anaeróbica e, consequentemente, menor chance de agressão ao meio ambiente. Por outro lado, a criação intensiva, totalmente confinada dentro das edificações foi determinante para o desenvolvimento da criação industrial de aves, necessitando portanto, o estabelecimento dos principais fatores que interferem na criação, seus riscos sanitários e as condições adequadas para que se atinja os interesses econômicos com os princípios de biosseguridade e bem estar animal (Naas et al., 2001).

Carrijo et al. (2002), avaliando o desempenho de quatro linhagens de frango tipo caipira (Paraíso Pedrês (PAPE), Vermelho Pesado (VEPE), Carijó Pesado (CAPE) e Pescoço Pelado (PEPE)), criadas em sistema semi-intensivo, alimentadas com uma dieta vegetal, isenta de antibióticos, coccidicidas e promotores de crescimento, verificaram que a linhagem PAPE obteve peso final significativamente superior $(\mathrm{P}<0,05)$ aos das linhagens CAPE, PEPE, não diferenciando de VEPE. Com relação ao ganho de peso, os autores verificaram que a linhagem PEPE apresentou resultados significativamente inferiores $(\mathrm{P}<0,05)$, não encontrando diferenças entre as demais linhagens, e também menor consumo de ração $(\mathrm{P}<0,05)$. Com relação à conversão alimentar, não houve diferenças significativas entre as linhagens de frango de corte tipo caipira.

A produção alternativa de frangos de corte tornou-se uma atividade de relevância para pequenos produtores das diferentes regiões do Brasil, tanto para sua subsistência nas propriedades rurais, como também para a produção comercial. 


\subsection{Fatores genéticos e de meio que atuam no desempenho de frangos de corte}

Nos dias de hoje, os avanços da avicultura têm permitido grandes resultados para o produtor de frangos de corte e, como consequiências, altos índices de eficiência produtiva.

As diferenças de desempenho de frangos de corte estão relacionadas com o potencial genético das linhagens, idade de abate, sexo, manejo, nutrição e sanidade. Além disso, mudanças no ambiente de criação, que diminuam as condições de estresse, são fatores essenciais para o aumento da produtividade e rentabilidade do sistema de produção.

Outro fator importante é a interação genótipo ambiente, em que os diferentes fatores ambientais que podem estar interferindo na produção animal possam ser avaliados (Reis, 1991).

Quando diferenças fenotípicas entre genótipos variam de ambiente para ambiente ou quando alguns genótipos são superiores em alguns ambientes e outros genótipos são superiores em outros, podemos dizer que está ocorrendo a interação genótipo ambiente. Segundo Bowman (1981), uma mudança no desempenho relativo de um caráter em dois ou mais genótipos, medidos em dois ou mais ambientes, pode ser definida como interação genótipo ambiente.

Interações podem, algumas vezes, envolver mudanças na ordem de posto (rank) dos genótipos entre ambientes ou levar à mudanças na magnitude das diferenças fenotípicas entre os diversos genótipos que mudam como consequiência do meio, porém, não altera a ordem do mérito (Reis, 1991).

Em aves, devido ao seu sistema de confinamento, é possível controlar com maior eficiência os fatores ambientais, entretanto, a necessidade de produção em larga escala tem exigido uma maior especialização nos diferentes setores de produção e, com isso, a formação de diferentes linhagens comerciais. 
Sabendo-se da importância das interações genótipo ambiente Lush $^{2}$ citado por Reis (1991), sugere que poder-se-ia escolher dois ou três ambientes mais representativos e criar um plantel especialmente adaptado a cada um deles.

Trabalhando com dois grupos genéticos de meio-irmãos de aves White Plymouth Rock que foram alimentadas com dietas contendo quantidade normal e baixa de proteínas, Sorensen (1977) verificou um decréscimo na taxa de crescimento de 37\% nos machos e de $25 \%$ nas fêmeas, quando estas aves foram alimentadas com a dieta de baixa proteína.

Com relação ao desempenho de diferentes materiais genéticos de frango de corte no consumo de ração, peso vivo e conversão de corte, Souza et al. (1993) trabalhando com as linhagens: Arbor Acres, Cobb, Hubbard e Ross verificaram que a linhagem Arbor Acres apresentou menor consumo de ração, menor peso vivo e melhor conversão alimentar quando comparada com as demais. $\mathrm{O}$ maior consumo de ração e a pior conversão foram os da linhagem Cobb.

Comparando o desempenho das linhagens Arbor Acres, Pilch e seus cruzamentos, Rosa et al. (1993) verificaram que as linhagens não influenciaram o desempenho produtivo de frangos de corte.

${ }^{2}$ LUSH, J.L. Mejoramiento animal. Buenos Aires, CEFADE, 1961, p.60-61. 
Pesquisando o efeito de diferentes linhagens sobre o desempenho de frangos de corte, Mendes et al. (1993) encontraram diferenças significativas entre elas para consumo de ração e conversão alimentar, aos 48 e 53 dias de idade. Com relação ao efeito de sexo, os mesmos autores verificaram que os machos apresentaram maiores consumos de ração e ganhos de peso e melhor conversão alimentar em relação às fêmeas.

Politi et al. (1994) comparando o peso médio inicial (PMI), peso médio final aos 47 dias (PMF), ganho de peso (GP), consumo de ração (CRM), conversão alimentar (CA), efeito de sexo e mortalidade de cinco linhagens comerciais de frangos de corte existentes no mercado brasileiro, verificaram que não ocorreu interação entre linhagem e sexo para quaisquer das características comparadas. Considerando apenas o efeito de sexo, os autores encontraram efeito positivo $(\mathrm{P}<0,05)$ dos machos para $\mathrm{PMF}$, GP e CA, porém, maior mortalidade. Encontraram diferenças significativas $(\mathrm{P}<0,05)$ entre as linhagens para PMI, PMF, GP e mortalidade.

Procurando verificar o efeito de duas linhagens comerciais de frangos de corte, criadas sob diferentes densidades populacionais e diferentes tipos de cama, Mizubuti et al. (1994) conduziram um experimento onde compararam três densidades populacionais (10, 12 e 14 aves/ $\mathrm{m}^{2}$ ), três tipos de cama (casca de arroz, capim colonião e capim elefante var. nappier) e duas linhagens (Arbor Acres e Hubbard) sobre o desempenho de frangos de corte nos períodos 1 (1 a 28 dias), 2 (29 a 45 dias) e total (1 a 45 dias). Os autores encontraram efeito significativo entre linhagens para consumo de ração nos períodos 1, 2 e total e para ganho de peso nos períodos 1 e 2, com a linhagem Hubbard apresentando as maiores médias. Não observaram efeito significativo da densidade populacional sobre as características estudadas. O consumo de ração foi afetado pela diferença entre cama nos períodos 2 e total, com menor média para a cama de capim nappier. Encontraram também efeito significativo da interação linhagem $\mathrm{x}$ camas, para consumo de ração no período total (menor consumo para combinação: Hubbard x capim nappier) e para conversão alimentar no período 1 (pior conversão para a combinação: Hubbard x capim colonião). 
Souza et al. (1994), ao avaliarem o desempenho de aves de ambos os sexos das linhagens Arbor Acres, Cobb, Hubbard e Ross, alimentadas nos períodos de 1 a 7,8 a 24, 25 a 41 e 42 a 49 dias de idade com as rações contendo $24,13 \%$ PB e 2.880 $\mathrm{kcal} \mathrm{EM} / \mathrm{kg}, 23,23 \%$ PB e $3000 \mathrm{kcal} \mathrm{EM} / \mathrm{kg}, 19,73 \%$ PB e $3200 \mathrm{kcal} \mathrm{EM} / \mathrm{kg}$ e 19,61\% PB e $3240 \mathrm{kcal} \mathrm{EM/kg}$, respectivamente, verificaram que na análise de variância dos dados em relação ao sexo, os machos da linhagem Arbor Acres apresentaram as menores médias de consumo de ração e ganho de peso e a melhor conversão alimentar. Não encontraram diferença significativa para o consumo de ração entre as linhagens Cobb, Hubbard e Ross. Com relação ao peso final, a linhagem Cobb foi inferior a Ross $(\mathrm{P}<0,05)$, mas não diferiu $(\mathrm{P}>0,05)$ da Hubbard e Ross. Com relação às fêmeas, os autores encontraram que a linhagem Arbor Acres teve as menores médias de consumo de ração e ganho e peso $(\mathrm{P}<0,05)$, assim como melhor conversão alimentar. A linhagem Cobb apresentou maior média de consumo de ração e ganho de peso $(\mathrm{P}<0,05)$, mas pior conversão alimentar.

Abreu et al. (1996c), ao compararem características produtivas de linhagens de frango de corte oriundas dos cruzamentos de três linhas macho e quatro linhas fêmeas da Granja de Melhoramento Genético de Aves da Universidade Federal de Viçosa, alimentadas com rações de diferentes níveis de energia metabolizável (2.900, 3050 e $3200 \mathrm{kcal} / \mathrm{kg}$ ), nas fases inicial (1 a 28 dia) e final (29 a 49 dias), não encontraram diferenças significativas entre os cruzamentos para peso vivo, consumo de ração e conversão alimentar. Com relação aos níveis de energia da ração na fase final, os autores encontraram efeito significativo no consumo total e na conversão alimentar total; sem, no entanto, influenciar o peso vivo aos 49 dias de idade, sendo o nível $3200 \mathrm{kcal}$ de EM o que proporcionou maior peso vivo, menor consumo de ração e melhor conversão alimentar.

Avaliando o efeito de três linhagens comerciais de frango de corte sobre o desempenho, Garcia et al. (1996) encontraram efeito significativo entre linhagens para ganho de peso, consumo e ração e peso vivo e não significativo para conversão alimentar. 
Viana et al. (2000) realizaram um experimento com objetivo de avaliar a diferença entre sete grupos genéticos de frangos de corte, obtidos a partir de cruzamentos entre dois genótipos pela UFV (M1 e F1) e de duas marcas comerciais (C1 e C2), e os efeitos de dietas com diferentes níveis de energia metabolizável no período final $\left(22^{\circ}\right.$ ao $42^{\circ}$ dia de idade), com 2900, 3050, 3200 e $3350 \mathrm{kcal} \mathrm{EM} / \mathrm{kg}$, sobre o peso vivo aos 42 dias de idade, peso de abate e rendimento e carcaça. Os autores encontraram diferenças entre grupos genéticos e sexo, independente do nível de energia, sobre o peso vivo, peso ao abate, peso da carcaça e de cortes, destacando-se as marcas comerciais C1 e C2. Em relação ao sexo, os machos apresentaram os melhores resultados para todas as características avaliadas.

Sendo assim, para que ocorram melhorias na produção animal é essencial realizar uma avaliação de como os fatores ambientais incidem sobre os indivíduos e como podemos criar animais mais bem adaptados nos mais diferentes ambientes.

\subsection{Rendimento de carcaça}

A indústria de frangos de corte está passando por uma fase de grandes desenvolvimentos tecnológicos e, aliada à modernização de seus produtos e ao crescente mercado internacional, tem mostrado grande preocupação em relação ao maior rendimento e a qualidade de carcaça.

A classificação e tipificação de carcaça apresentam-se como fatores de grande importância comercial nos dias de hoje. Várias são as causas dessas mudanças, porém entre as principais, destacam-se o aumento da demanda de cortes nobres e a exigência de alguns países importadores, com relação a carcaças de boa conformação, menor peso e quantidade de gordura abdominal, visando à diminuição dos prejuízos da indústria, consumidor e produtor.

Em relação ao termo rendimento de carcaça, Ribeiro (1989) relata ser a relação percentual existente entre as partes comestíveis e não comestíveis mais as perdas. A qualidade de carcaça refere-se a parte visual de apresentação da mesma, associada à composição química e as características organolépticas da carcaça. 
Segundo Mendes (1990), quando se leva em consideração o segmento completo de uma operação totalmente integrada, que compreende a produção de pintos de corte, engorda de frangos, abate e processamento, a característica que mais contribui para maximizar o retorno econômico é o rendimento de carcaça e que vários fatores podem influenciar neste rendimento como a linhagem, a nutrição, o sexo, o peso ao abate, o tempo de sangria, a temperatura de escaldamento, o resfriamento da carcaça e a quantidade de gordura na carcaça.

Acar et al. (1991) ao avaliarem o rendimento de carcaça e de partes de frangos de corte dos cruzamentos Peterson x Arbor Acres e Ross x Ross, abatidos com seis e oito semanas de idade, observaram diferenças na qualidade de carcaça entre os cruzamentos. O maior rendimento de carcaça, de filé de peito e menor percentagem de gordura abdominal foram encontrados no cruzamento Ross x Ross e, com relação a percentagem de rendimento de asa e dorso, o cruzamento Peterson x Arbor Acres, apresentou os maiores resultados, porém, não foram encontrados diferenças no rendimento de coxa.

Os rendimentos de carcaça e de cortes de frango são características de alto valor econômico na produção de carne e, à medida que as aves se tornam mais pesadas, estes rendimentos aumentam.

Mendes et al. (1993a) realizando um estudo para avaliar o efeito do peso do abate sobre o rendimento de carcaça de frangos de corte da linhagem Arbor Acres, de ambos os sexos, com pesos de abate de 1,5, 2,0 e 2,5 kg, respectivamente, com 37, 44 e 51 dias de idade, verificaram que o rendimento carcaça eviscerada (sem cabeça, pescoço e patas $)$, aumentou $(\mathrm{P}<0,05)$ e a percentagem de cabeça diminuiu $(\mathrm{P}<0,05)$ à medida que as aves eram abatidas com pesos mais elevados. As percentagens de peito, dorso e asas nas aves abatidas com 1,5 kg foram menores que aquelas abatidas com 2,0 e 2,5 kg. $\mathrm{O}$ rendimento de pernas nas aves abatidas com 2,5 $\mathrm{kg}$ foi maior que com 2,0 e 1,5 kg. Os machos apresentaram maiores percentagens $(P<0,05)$ de patas e pernas que as fêmeas, enquanto que estas foram superiores em peito e asas.

Estudando o efeito do cruzamento de linhagens sobre o rendimento de carcaça de frangos de corte, Mendes et al. (1994) encontraram efeito da linhagem sobre 
a percentagem de carcaça eviscerada (sem patas, cabeça e pescoço) e sobre a percentagem de pernas, mas não observaram diferenças sobre as percentagens de asas, dorso, cabeça, pescoço, patas, moela, fígado, coração e gordura abdominal.

Abreu et al. (1996a) realizaram um experimento para verificar os efeitos de cruzamentos e de níveis de energia da ração sobre o rendimento de carcaça e de partes e deposição de gordura abdominal de frangos de corte. Concluíram que houve diferenças entre os cruzamentos para o peso de peito, costado anterior, moela e gordura abdominal e, em relação aos níveis de energia da ração nas fases inicial e final de criação, encontraram influências apenas para o peso de pescoço e costado anterior, respectivamente. Para o peso das demais características não foram encontrados efeitos dos níveis de energia.

Abreu et al. (1996b) ao avaliarem os efeitos dos níveis de energia da ração e cruzamentos sobre a composição da carcaça de frangos de linha de corte, encontraram diferença entre os cruzamentos apenas para o teor corporal de gordura e, em relação aos níveis de energia da ração na fase final, encontraram efeitos sobre os teores corporais de gordura e proteína de forma linear e positiva e, para o teor de água de forma linear e negativa.

Fernandes et al. (2002) avaliando o rendimento de carcaça e de partes de frangos de corte de diferentes cruzamentos entre reprodutores machos das linhagens comerciais Ross (R), Isa Vedette (I), Shaver (S) e Hubbad (H) com fêmeas das mesmas linhagens, em sistemas de produção com bebedouros pendular ou nipple, não encontraram efeito significativo do tipo de bebedouro sobre o rendimento de carcaça, independente da linhagem, entretanto, o rendimento de peito foi maior para $o$ cruzamento IH e o cruzamento $\mathrm{SH}$, de menor peso corporal, evidenciou rendimentos de carcaça inferiores a todos os demais.

Com relação à avaliação do efeito de sexo afetando o rendimento de carcaça de frangos de corte, muitos resultados são contraditórios, porém sabe-se que as fêmeas apresentam maior porcentagem de gordura abdominal, peito e asas, enquanto que os machos são superiores em coxas, patas e dorso (Mendes, 1989). 
Com o objetivo de verificar o efeito da linhagem e da idade de abate sobre o rendimento de carcaça de frangos de corte, Mendes et al. (1993b) realizaram um experimento, onde aos 48 e 53 dias de criação foram abatidas 30 aves de cada sexo das linhagens Arbor Acres e Hubbard, após um período de oito horas de jejum. Os autores verificaram que os frangos Arbor Acres apresentaram maiores porcentagens de carne de pernas que os Hubbard (com pele), tanto em relação ao peso vivo (\%/PV) como em relação ao peso de carcaça eviscerada (\%/CE). As aves abatidas aos 53 dias apresentaram maiores \%/PV de carcaça eviscerada, osso de peito e dorso e menores \%/PV de carne de pernas, que aos 48 dias. Ainda aos 53 dias, as aves apresentaram maiores $\% / \mathrm{CE}$ de osso de peito e dorso e menores $\% / \mathrm{CE}$ de carne de peito (sem pele) e carne de pernas (com pele) que aquelas abatidas aos 48 dias. Com relação ao sexo, os machos apresentaram maiores \%/PV de ossos de pernas, cabeça mais pescoço e patas que as fêmeas e estas foram superiores em \%/PV de pele de peito. Considerando o peso da carcaça, os machos apresentaram maiores porcentagens de carne de pernas (com pele) e menores de pele de peito que as fêmeas.

Mendes et al. (1993c), ao comparar o efeito do nível nutricional da dieta e do sexo sobre o rendimento de carcaça de frangos de corte da linhagem Arbor Acres, verificaram que aos 49 dias de idade as dietas com níveis normais resultaram em maiores percentagens de sobrecoxas e cabeça e menores percentagens de gordura abdominal que as dietas com níveis baixos e, as percentagens de carcaça eviscerada (sem patas, cabeça e pescoço), peito, coxas, asas, dorso, patas, pescoço, fígado, moela e coração não foram afetados pelo tipo de dieta. Em relação ao sexo, os autores constataram que os machos apresentaram maiores percentagens de coxas, patas, cabeça e pescoço que as fêmeas e estas foram superiores em carcaça eviscerada, peito, asas, dorso e gordura abdominal.

O efeito da linhagem e do sexo sobre o rendimento de carcaça de frangos de corte foi comparado por Poloti et al. (1994). Os autores observaram que houve diferença significativa $(\mathrm{P}<0,05)$ entre as linhagens para percentagens de carne de peito, pele de peito e osso de coxa e, entre os sexos, os machos apresentaram maior $(\mathrm{P}<0,05)$ rendimento de carcaça e carne de coxa e as fêmeas maior rendimento de carne de peito. 
Quando consideraram os cortes secundários, observaram diferenças significativas entre as linhagens para asa, dorso, patas, cabeça e gordura abdominal, e, entre sexos, os machos apresentaram maior percentagem de dorso, patas e cabeça, observando nas fêmeas, maior percentagem de gordura abdominal.

Lisboa (1995), analisando o rendimento de carcaça, de cortes nobres e de gordura abdominal de 3 grupos genéticos de frango de corte, denominados UFV1, UFV2, UFV3, produzidos na Universidade Federal de Viçosa, de ambos os sexos, recebendo diferentes níveis de proteínas $(16,5 ; 18,0 ; 19,5$ e 21,0\%) no período de 22-42 dias de idade, verificou que os grupos genéticos influíram significativamente nos rendimentos de carcaça, peito $(\mathrm{P}<0,01)$ e sobrecoxa $(\mathrm{P}<0,05)$. Com relação ao sexo, os machos foram superiores no rendimento de coxa $(\mathrm{P}<0,01)$ e sobrecoxa $(\mathrm{P}<0,05)$, porém, observou maiores rendimentos de peito e de gordura abdominal $(\mathrm{P}<0,01)$ para as fêmeas. Verificando o efeito crescente do nível de proteína, o autor constatou diminuição no rendimento de carcaça eviscerada $(\mathrm{P}<0,05)$ e de gordura abdominal $(\mathrm{P}<0,01)$, porém, aumento linear no rendimento de coxa.

Schmidt \& Custódio (1998) estudaram características de carcaça em populações de híbridos de frango de corte desenvolvidas no Departamento de Genética da ESALQ/USP (LT, IP e EG) e uma linhagem comercial (HC1-Ross), e verificaram que os genótipos não apresentaram diferenças quanto à percentagem de gordura abdominal expressa em relação ao peso vivo e peso eviscerado. Contudo, quando a avaliação foi feita em função da quantidade de gordura aderida à carcaça, a população LT apresentou maior deposição. Com relação ao rendimento de carcaça, a população LT apresentou baixo rendimento em comparação com os demais materiais genéticos. Os autores verificaram que, ao analisar o efeito de sexo, as fêmeas apresentaram maior rendimento de carcaça e maior acúmulo de gordura abdominal. Neste mesmo estudo foi observado uma interação significativa de genótipo com sexo para as características de rendimento de carcaça e gordura abdominal.

Figueiredo et al. (2002) realizaram um experimento com objetivo de avaliar o peso da cabeça, dos pés, do coração, dos pulmões, do fígado, da moela e o comprimento do intestino das linhagens de frango de corte Cobb, Ross e duas da 
Embrapa (E21 e E22), de ambos os sexos, aos 28, 35, 42, 4956 dias de idade, sendo alimentadas com ração para rápido crescimento. Verificaram que todos os órgãos aumentaram linearmente de tamanho com a idade, porém, proporcionalmente, cabeça, coração, pulmão, fígado, moela e intestinos decresceram, mas os pés aumentaram. A linhagem Ross apresentou órgãos proporcionalmente menores do que as demais e, os machos apresentaram órgãos internos maiores ou mais pesados do que as fêmeas.

A diminuição das condições de estresse devido às mudanças no ambiente de criação podem melhorar o bem estar animal e a produção, consequentemente, o rendimento de carcaça de frangos de corte.

Portanto, avaliações das diferentes condições adversas no sistema de produção devem ser realizadas freqüientemente, para que mudanças na cadeia produtiva da avicultura possam melhorar o sistema de criação e os animais a serem criados.

Bertechini et al. (1991), ao avaliarem os efeitos das temperaturas ambiente $\left(17,1,22,2\right.$ e $\left.27,9{ }^{\circ} \mathrm{C}\right)$, dos diferentes níveis de energia da ração $(2.800,3.000$ e $3.200 \mathrm{kcal} / \mathrm{kg}$ ) e do sexo sobre o rendimento de carcaça, gordura abdominal e gordura livre aos 49 dias de idade, constataram que estas características não foram afetadas pela variação da temperatura ambiente $(\mathrm{P}>0,05)$, porém em relação ao sexo, os machos foram superiores as fêmeas no rendimento de carcaça e gordura abdominal livre. Os autores também verificaram que o aumento do conteúdo energético da ração provocou um acréscimo na deposição de gordura abdominal, especialmente com ração de 3.200 $\mathrm{kcal} / \mathrm{kg}$.

Oliveira Neto et al. (2000) verificando o efeito da temperatura termoneutra $\left(23,3\right.$ ñ $\left.0,58{ }^{\circ} \mathrm{C}\right)$ ou quente $\left(32,3\right.$ ñ $\left.0,31{ }^{\circ} \mathrm{C}\right)$ sobre o desempenho de características de carcaça de frangos de corte da linhagem Hubbard, alimentados com dietas contendo dois níveis de energia metabolizável, 3075 e $3300 \mathrm{kcal} \mathrm{EM/kg}$, no período de 22 a 42 dias de idade, constataram que o estresse de calor influenciou negativamente o desempenho, reduziu o rendimento de peito e de órgãos vitais, bem como aumentou a gordura abdominal dos frangos de corte, independente do nível energético da ração. 
Lana et al. (2000) pesquisando o efeito da temperatura ambiente (máxima de $30,2{ }^{\circ} \mathrm{C}$ e mínima de $20,1{ }^{\circ} \mathrm{C}$ ) e alta (máxima de $36,0{ }^{\circ} \mathrm{C}$ e mínima de $31,0{ }^{\circ} \mathrm{C}$ ), no período de 1 a 42 dias de idade, do sexo e da restrição alimentar (2 dias de restrição, com ração à vontade e controlada após jejum e, 4 dias de restrição, com ração à vontade e controlada após jejum), sobre o rendimento de carcaça de frangos de corte, verificaram que os rendimentos de carcaça e de cortes nobres não foram influenciados pela temperatura, pelo programa de restrição alimentar e pelo sexo, porém, as fêmeas apresentaram maior teor de gordura na carcaça.

A boa integridade física das aves antes do abate é também uma importante etapa na cadeia produtiva do frango e corte, pois as contusões devido ao manejo de criação, à captura das aves no carregamento, transporte e descarregamento na plataforma do abatedouro, são fatores que interferem diretamente na qualidade de carcaça e no custo de produção do frango.

Com objetivo de avaliar o efeito do tipo de captura de frangos de corte sobre a qualidade de carcaça, Leandro et al. (2001) realizaram um experimento onde foram testados os tipos de apanha, pelo dorso e pelo pescoço das aves, aos 45 dias de idade, em relação ao número e frangos parcialmente e totalmente condenados devido às lesões cutâneas oriundas de trauma mecânico (contusões) e fraturas que ocorreram antes da sangria e apresentavam sangue (fratura vermelha). Os resultados encontrados por esses autores foram que as aves capturadas pelo dorso apresentaram menor número de contusões de carcaça e menos condenações no abatedouro, do que aquelas que foram pegas pelo pescoço.

A nutrição tem considerável responsabilidade pelo sucesso da avicultura e, objetivando melhorar o rendimento de carcaça, vários trabalhos têm surgido buscando manipular os níveis nutricionais das dietas de frango de corte, a fim adequar as exigências para a obtenção de maiores rendimentos.

Com o objetivo de verificar o efeito do nível de energia e do sexo no rendimento de carcaça de frangos de corte, Garcia et al. (1993) realizaram um experimento com dietas contendo 2750, 2900, 3050 e $3200 \mathrm{kcal} / \mathrm{kg}$ EM, respectivamente, onde os níveis de proteína, cálcio, fósforo, lisina e metionina+cistina, 
foram adequados ao nível de energia da dieta. As aves foram abatidas aos 56 dias de idade, após um período de jejum de 8 horas. Foi constatado que o nível de energia da dieta afetou $(\mathrm{P}<0,05)$ o rendimento de coxas, cabeça, moela e gordura abdominal, mas não teve efeito $(\mathrm{P}>0,05)$ sobre o rendimento de carcaça eviscerada (sem cabeça, pescoço e patas), peito, sobrecoxa, asas, dorso, pescoço, patas, fígado e coração. Os machos apresentaram percentagens mais altas $(\mathrm{P}<0,05)$ de sobrecoxas, cabeça e patas e mais baixas de dorso, moela e gordura abdominal que as fêmeas.

Whitaker et al. (2002) realizaram um experimento com frangos de corte da linhagem comercial Ross, sexados, com objetivo de avaliar o efeito dos níveis adicionais de metionina $(0,38 \% ; 0,42 \% ; 0,46 \% ; 0,50 \%$ e $0,54 \%$ de DL-Metionina com valores correspondentes à 100\%, 110\%,120\%, 130\% e 140\% das recomendações do NRC (1994)). Os autores verificaram que o aumento do nível de metionina na dieta no período de 22 a 42 dias de idade não afetou o desempenho e os rendimentos de carcaça, cortes principais e secundários, gordura abdominal e composição química da carcaça, para ambos os sexos, sugerindo que a suplementação mais baixa foi adequada.

Almeida et al. (2002) ao avaliarem o desempenho produtivo, rendimento de carcaça, gordura abdominal e peito desossado de frangos de corte, sexados, alimentados com níveis normais de lisina $(1,10 ; 1,00$ e $0,85 \%)$, recomendados pelo NRC (1994), nas rações inicial (0-21 dias), crescimento (22-42 dias) e retirada (43-49 dias), respectivamente, e níveis altos nas rações inicial (1,21\% de lisina), de crescimento (1,10\% de lisina) e retirada (1,02\% de lisina), abatidos aos 28, 35, 42 e 49 dias de idade, verificaram que os níveis de lisina não afetaram $(\mathrm{P}>0,05)$ o ganho de peso, a conversão alimentar e o rendimento de carcaça, mas os índices altos resultaram em menores percentagens de gordura abdominal quando comparados aos níveis baixos de lisina, nas fêmeas. A inclusão de lisina na dieta não melhorou o rendimento de carcaça e de peito aos 28, 35, 42 e 49 dias de idade $(\mathrm{P}>0,05)$.

Mendes et al. (1995) ao compararem o efeito da relação energia-proteína da dieta sobre a gordura abdominal presente na carcaça de frangos de corte, verificaram que à medida que se aumentou a relação (140, 145, 150, 155 e 160), houve um incremento na percentagem de gordura abdominal $(\mathrm{P}<0,01)$. 
O uso de aditivos nas rações de frangos de corte tem trazido excelentes resultados a nível de produção, porém é crescente a preocupação, em todo o mundo, em relação ao uso de antibióticos na forma terapêutica e como promotores de crescimento em animais destinados à produção de alimentos.

Com objetivo de avaliar os efeitos do uso do probiótico Colostrum avis na alimentação de frangos de corte sobre os parâmetros de desempenho, rendimento de carcaça e gordura abdominal em comparação aos aditivos tradicionais, Moreira et al. (2001) realizaram um experimento e concluíram que o uso do probiótico na alimentação promoveu desempenhos semelhantes aos promotores químicos aos 44 e 49 dias de idade e que o uso do probiótico não teve efeito sobre o rendimento de carcaça, partes e gordura abdominal nos frangos de corte, porém a suplementação das aves com os promotores químicos avaliados propiciaram um maior rendimento de peito.

A restrição alimentar também tem sido pesquisada como uma alternativa de manejo para melhorar a qualidade da carcaça, sem afetar o desempenho produtivo e econômico dos frangos (Sugeta et al. 2001), e também com o objetivo de reduzir os problemas metabólicos, de esqueleto e a alcalose respiratória provocada pelo estresse calórico dos frangos (Leu, 2000).

Um dos fundamentos básicos desta técnica é a redução da exigência de mantença energética relacionada ao menor peso corporal e adaptação metabólica orgânica na fase de restrição, acompanhada de posterior melhoria na eficiência alimentar na fase de realimentação sem comprometer o peso e abate (Yu \& Robinson ${ }^{3}$ citado por Sugeta et al. 2001).

Portanto, tendo em vista as exigências do mercado consumidor, são necessárias constantes avaliações nas condições do sistema de produção, para que, aspectos ligados à eficiência da produção e ao bem estar animal, possam melhorar a

\footnotetext{
${ }^{3}$ YU, M.W., ROBINSON, F.E. The application of short term feed restricion to broilers chickens production: a review. Journal Applied. Poutry Reserch, v. 1, n.1, p. 147-153, 1992.
} 
cadeia produtiva da avicultura, e com isso, obter melhores resultados de rendimento e qualidade de carcaça nos animais a serem criados. 


\section{MATERIAL E MÉTODOS}

\subsection{Local}

$\mathrm{O}$ experimento foi conduzido nas instalações experimentais do Departamento de Genética da Escola Superior de Agricultura "Luiz de Queiroz" da Universidade de São Paulo, localizada no município de Piracicaba, Estado de São Paulo.

O período experimental teve início no dia 07 de dezembro de 2000 e se estendeu até 02 de março de 2001.

\subsection{Animais}

Foram utilizados 1120 pintos de um dia provenientes de ovos de quatro linhagens alternativas de frango de corte tipo caipira, sendo duas comerciais e duas experimentais, desenvolvidas no Departamento de Genética da ESALQ/USP. As linhagens foram: Comercial Label Rouge (crescimento lento), Comercial Paraíso Pedrês (crescimento rápido), Experimental Caipirinha (crescimento lento), Experimental 7P (crescimento rápido).

Os ovos das quatro linhagens foram incubados simultaneamente, à temperatura de 36,9 a $37,1{ }^{\circ} \mathrm{C}$ com umidade relativa do ar de 87,5 a $88 \%$ por um período de 18 dias. A transferência dos ovos para a câmara de eclosão foi realizada no décimo oitavo dia, onde permaneceram até o vigésimo primeiro dia a uma temperatura de 36,4 a $36,6{ }^{\circ} \mathrm{C}$ com umidade relativa do ar de 90,0 a $90,5 \%$.

Após o nascimento, as aves foram pesadas no incubatório e vacinadas contra a doença de Marek, aneladas para identificação individual e, a seguir, alojadas 
sem separação de sexo em 32 boxes experimentais, sendo oito boxes por Inhagem, com uma lotação de 35 pintos/box.

\subsection{Tratamentos}

Os tratamentos experimentais consistiram de quatro linhagens alternativas de frango tipo caipira, sendo duas comerciais e duas experimentais, criadas nos sistemas intensivo e semi-intensivo.

No sistema intensivo de criação as aves ficaram confinadas no galpão durante todo o experimento e no sistema semi-intensivo o acesso livre ao pasto ocorreu depois dos 21 dias de idade.

\section{TRATAMENTOS :}

1- Linhagem Label Rouge (LR) no sistema intensivo de criação;

2- Linhagem Label Rouge (LR) no sistema semi-intensivo de criação;

3- Linhagem Caipirinha (CP) no sistema intensivo de criação;

4- Linhagem Caipirinha (CP) no sistema semi-intensivo de criação;

5- Linhagem 7P no sistema intensivo de criação;

6- Linhagem 7P no sistema semi-intensivo de criação;

7- Linhagem Paraíso Pedrês (PP) no sistema intensivo de criação;

8- Linhagem Paraíso Pedrês (PP) no sistema semi-intensivo de criação.

\subsection{Instalações, preparação e condução do experimento}

\subsubsection{Desempenho produtivo}

Os galpões experimentais, estavam dispostos na orientação sudestenordeste, com as seguintes dimensões: $24 \mathrm{~m}$ de comprimento por 8 de largura e pé 
direito de 2,7 m. Os galpões possuíam muretas laterais de alvenaria com 0,60 m de altura, piso de concreto, lanternim, cobertura em telhas de barro tipo francesa, cortinas e tela até o teto. Os galpões eram divididos em 16 boxes cada um, dispostos em duas fileiras longitudinais de 8 boxes em cada lado. A cada dois boxes em adjacentes, um tinha uma abertura na parede externa dando acesso a um piquete. A área interna dos boxes era de $4,5 \mathrm{~m}^{2}$.

Os piquetes possuíam 5,5 $\mathrm{m}$ no lado contíguo aos boxes por $6,95 \mathrm{~m}$ de largura com 38,22 $\mathrm{m}^{2}$ de área total. Era cercado com tela de galinheiro a uma altura de $1 \mathrm{~m}$. A grama utilizada foi a batatais. A sombra incidente nos pastos era somente a proveniente da lateral do galpão, portanto somente em determinadas horas do dia ela estava presente. A taxa de lotação dentro do galpão foi de 7,7 aves $/ \mathrm{m}^{2}$ e, no pasto, de $1,09 \mathrm{~m}^{2}$ de área por ave.

Cada box continha um sistema de aquecimento por meio de lâmpada incandescente (150 Watts), localizada na região central e suspensa a $0,50 \mathrm{~m}$ do piso, um bebedouro do tipo pressão (com capacidade de 3 litros de água), um comedouro tubular infantil (com capacidade de $5 \mathrm{~kg}$ de ração), além de duas placas de eucatex que formavam um círculo de proteção e promoviam um melhor controle da temperatura ambiente. Foi utilizado como cama para as aves casca de arroz, espalhada homogeneamente por todo o box a uma espessura de $10 \mathrm{~cm}$.

As lâmpadas foram acesas previamente ao alojamento das aves para que o ambiente atingisse a temperatura de $32^{\circ} \mathrm{C}$. As lâmpadas de aquecimento foram mantidas acesas nos 7 primeiros dias e, as cortinas de plástico nas laterais do galpão fechadas. $\mathrm{O}$ aquecimento do galpão após este período foi feito de acordo com a temperatura ambiente e o comportamento das aves, permanecendo as lâmpadas acesas somente no período noturno até o $14^{\circ}$ dia. A partir da terceira semana experimental as lâmpadas de aquecimento foram totalmente retiradas e o manejo, de subir e abaixar as cortinas, passou a ser realizado mediante a resposta comportamental das aves.

Após o sétimo dia, os bebedouros do tipo pressão e comedouros tubulares infantis foram substituídos por bebedouros do tipo pendular (com capacidade de 1 litro 
de água) e comedouros tubulares para aves adultas (com capacidade de $20 \mathrm{~kg}$ de ração). Foi utilizado um equipamento de cada tipo por box.

A iluminação artificial em cada um dos galpões foi feita através de 6 lâmpadas incandescentes de 60 watts cada, dispostas na parte central a uma altura de 2,30 $\mathrm{m}$ do piso, que permaneceram acesas durante a noite por todo o período experimental.

A temperatura máxima e mínima interna nos galpões durante o período experimental foi de $33{ }^{\circ} \mathrm{C}$ e de $22,5{ }^{\circ} \mathrm{C}$, respectivamente, com média de $27,75{ }^{\circ} \mathrm{C}$. A umidade máxima e mínima interna nos galpões foi de $76 \%$ e de $44 \%$, respectivamente, com média de 60\%. O monitoramento foi realizado diariamente às 9:00 horas através de termômetros de máxima e mínima, localizados no centro do galpão a $60 \mathrm{~cm}$ do piso. Com relação à temperatura e a umidade relativa do ar no pasto, os resultados encontrados foram de $33{ }^{\circ} \mathrm{C}$ de temperatura máxima, $22,5{ }^{\circ} \mathrm{C}$ de temperatura mínima e $27,0{ }^{\circ} \mathrm{C}$. de média; com $86 \%$ de umidade relativa máxima, $48 \%$ de umidade relativa mínima e com média de $67 \%$. O monitoramento foi realizado diariamente durante o período de 35 a 75 dias de idade das aves, através de termômetros de globo negro, que medem a sensação térmica da aves em função do ambiente, e de higrômetros que medem a umidade relativa.

No sistema semi-intensivo de criação, quando as aves atingiram 21 dias de idade, o acesso ao pasto foi aberto, permitindo a livre passagem para o pasto. As aves receberam vacinação contra as doenças de Newcastle e Gumboro na água de bebida, aos 7 e 21 dias de idade, conforme recomendação do fabricante das vacinas.

As pesagens foram realizadas semanalmente dentro de cada linhagem até as mesmas atingirem o peso estipulado de $2300 \mathrm{~g}$. Até a terceira pesagem, todas as aves de um mesmo box foram pesadas em conjunto e as demais pesagens foram realizadas individualmente com separação do sexo. A balança utilizada foi do tipo dinamômetro, com capacidade até $5 \mathrm{~kg}$ e precisão de $20 \mathrm{~g}$. 


\subsubsection{Condições pré e pós abate}

A coleta de dados foi interrompida no dia em que cada parcela, por estimativa, alcançou o peso vivo médio aproximado de $2300 \mathrm{~g}$. Este procedimento foi adotado visando eliminar o efeito do peso final sobre variáveis de desempenho de carcaça.

Em cada uma dessas idades, foi retirada uma amostra de 6 aves por repetição ( 3 machos e 3 fêmeas) para abate após um período de jejum de 12 horas. As aves foram marcadas individualmente, substituindo-se os anéis de metal na asa por anéis de plástico na pata. Todos os abates, seguindo-se os mesmos procedimentos, foram realizados no abatedouro da Faculdade de Medicina Veterinária e Zootecnia da Unesp, Campus de Botucatu-SP e, os transportes foram realizados somente durante a madrugada, com objetivo de diminuir o estresse da viagem.

Chegando no abatedouro, as aves foram descarregadas na plataforma e pesadas uma a uma. Após o abate, foram realizados cortes do tipo industrial e todas as determinações foram feitas na carcaça seca. Foi considerada como gordura abdominal a gordura presente na região retroperitonial e aquela existente ao redor da moela. As percentagens foram calculadas com base no peso de plataforma e, para análise

estatística, foram transformadas em arc sen $\sqrt{\% / 100}$, considerando-se cada ave como uma unidade experimental. Para a comparação das médias dos tratamentos utilizou-se o teste de Tukey.

\subsection{Rações}

O programa de alimentação do período experimental foi dividido em duas fases, a fim de atender as exigências de cada fase de desenvolvimento das aves. As dietas utilizadas foram à base de milho e farelo de soja, usando-se a composição média desses ingredientes com o objetivo de atender níveis nutricionais propostos por Rostagno (1996). 
Foram utilizadas rações comerciais produzidas pela COPLACANA Cooperativa dos Plantadores de Cana do Estado de São Paulo, situada na cidade de Piracicaba-SP.

As fases de criação foram:

$1^{\mathrm{a}}$ fase: ração inicial - do $1^{\mathrm{o}}$ ao $21^{\circ}$ dia de idade;

$2^{\mathrm{a}}$ fase: ração engorda - do $22^{\circ}$ dia até final do experimento.

$\mathrm{Na}$ fase inicial a energia metabolizável utilizada foi de $3000 \mathrm{kcal} \mathrm{EM} / \mathrm{kg}$ e 20,0\% de proteína bruta (PB) e para a fase de engorda utilizou-se $3150 \mathrm{kcal} \mathrm{EM/kg} \mathrm{e}$ $17,00 \%$ de PB.

Durante todo o período experimental a ração e água foram fornecidas ad libitum para as aves. A composição percentual das rações, bem como os níveis calculados estão apresentados na Tabela.1.

Tabela 1 Composição percentual e valores calculados das rações.

\begin{tabular}{|c|c|c|}
\hline INGREDIENTES & INICIAL $^{\top}$ & ENGORDA $^{2}$ \\
\hline Milho & 60,63 & 68,00 \\
\hline Farelo de trigo & 2,50 & 2,00 \\
\hline Farelo de soja & 31,25 & 23,75 \\
\hline Óleo de soja degomado & 0,41 & 1,04 \\
\hline $\begin{array}{l}\text { Suplemento } \\
\text { VALORES CALCULADOS }\end{array}$ & 5,21 & 5,21 \\
\hline $\mathrm{EM}(\mathrm{kcal} / \mathrm{kg})$ & 3.000 & 3.150 \\
\hline PB (\%) & 20,00 & 17,00 \\
\hline Cálcio (\%) & 0,92 & 0,90 \\
\hline Fósforo disponível (\%) & 0,30 & 0,29 \\
\hline
\end{tabular}


2- Enriquecimento por $\mathrm{kg}$ do produto: ácido fólico $0,4 \mathrm{mg}$; antioxidante $100 \mathrm{mg}$; coccidiostático $60 \mathrm{mg}$; promotor de crescimento $30 \mathrm{mg}$; cobre $65 \mathrm{mg}$; ferro $50 \mathrm{mg}$; iodo $1 \mathrm{mg}$; lisina $0,3 \mathrm{~g}$; manganês $60 \mathrm{mg}$; metionina $1,35 \mathrm{~g}$; selênio $0,2 \mathrm{mg}$; sódio $1,5 \mathrm{~g}$; vit. A $6000 \mathrm{UI}$; vit. B12 $10 \mathrm{mcg}$; vit.D3 2000 UI; vit.E 10 $\mathrm{mg}$; vit k3 0,80 mg; zinco $45 \mathrm{mg}$; pantotenato de cálcio $8 \mathrm{mg}$; niacina $20 \mathrm{mg}$; cloreto de colina $0,24 \mathrm{~g}$; biotina $60 \mathrm{mcg}$; piridoxina $2 \mathrm{mg}$; tiamina $1,8 \mathrm{mg}$; riboflavina $4,5 \mathrm{mg}$.

\subsection{Variáveis estudadas}

\subsubsection{Idade das aves ao atingir o peso de $2300 \mathrm{~g}$ (Idade 2300)}

As aves de cada parcela foram pesadas individualmente a cada semana até os 54 dias de idade e, as demais pesagens, foram realizadas até cada linhagem atingir o peso vivo médio estipulado de $2300 \mathrm{~g}$.

\subsubsection{Ganho de peso médio diário (GPMD)}

Foram calculados os ganhos de peso diários de cada parcela desde o nascimento até atingir o peso estipulado de $2300 \mathrm{~g}$.

\subsubsection{Consumo médio de ração $(\mathrm{CR})$}

O consumo médio semanal de ração foi determinado dividindo-se a diferença entre a ração fornecida durante a semana e a sobra de ração pesada ao final da mesma pelo número de aves por box. As médias semanais foram totalizadas para resultar no consumo médio por ave na parcela.

\subsubsection{Conversão alimentar (CA)}

A conversão alimentar foi calculada dividindo-se o consumo de ração médio pelo ganho de peso médio das aves do box no período estudado. 


\subsubsection{Mortalidade}

$\mathrm{O}$ registro de mortalidade era feito no dia do evento, retirando-se a ave morta assim que encontrada. A mortalidade foi expressa em porcentagem nos períodos estudados.

\subsubsection{Rendimento das partes principais da carcaça}

As características consideradas como rendimento de partes principais da carcaça foram as percentagens de: carcaça eviscerada, pernas, asa, peito, dorso, carne de perna e carne de peito.

\subsubsection{Rendimento das partes secundárias da carcaça}

As características consideradas como rendimento de partes secundárias da carcaça foram as percentagens de: osso de perna, osso de coxa pele de perna, pele de coxa, gordura abdominal, vísceras, pés e cabeça + pescoço.

\subsection{Delineamento experimental e análise estatística}

O delineamento experimental foi em faixa com parcelas subdivididas, sendo as linhagens alocadas nas parcelas e o sistema de criação (confinado ou não) nas sub-parcelas. A análise de variância das características estudadas foi processada pelo programa de computação SAS (1985), no procedimento GLM (General Linear Models), e a comparação de médias foi realizada utilizando-se o teste de Tukey $(\mathrm{p}<0,05)$.

O modelo matemático utilizado para análise de desempenho foi 0 seguinte:

$$
Y i j=u+L i+e i+S I j+e j+(L x \text { SI }) i j+e i j
$$

onde, 
Yij = valor observado da ave da linhagem i, no sistema de criação j;

$\mathrm{u}=$ média geral;

$\mathrm{Li}=$ efeito da linhagem $\mathrm{i}$;

ei = erro a (aleatório);

$\mathrm{SIj}=$ efeito do sistema de criação j;

ej = erro b (aleatório);

(L x SI)ij = efeito da interação da linhagem i com o sistema de criação j;

eij = erro c (aleatório).

As análises estatísticas dos rendimentos das partes principais e secundárias da carcaça foram feitas também usando o programa SAS, de acordo com o seguinte modelo:

$$
Y i j k=u+L i+e i+S I j+e j+(L x S I) i j+e i j+S k+(S x L) i k+e i j k
$$

onde,

Yijk = valor observado da ave da linhagem i, no sistema de criação j, no sexo k;

$\mathrm{u}=$ média geral;

$\mathrm{Li}=$ efeito da linhagem $\mathrm{i}$;

ei = erro a (aleatório);

SIj = efeito do sistema de criação $\mathrm{j}$;

ej = erro b (aleatório);

(L x SI)ij = efeito da interação da linhagem i com o sistema de criação j;

eij = erro c (aleatório);

$\mathrm{Sk}=$ efeito do sexo $\mathrm{k}$;

(S x L)ik = efeito da interação do sexo k com a linhagem i

eijk = erro d (aleatório). 


\section{RESULTADOS E DISCUSSÃO}

\subsection{Desempenho produtivo}

Através da análise de variância (Tabela 2), são apresentados os efeitos das linhagens, sistema de criação e das interações linhagem x sistema de criação, no desempenho de frangos de corte tipo caipira. Os resultados observados detectaram diferenças significativas nos valores de idade das aves ao atingirem o peso $2300 \mathrm{~g}$ (idade 2300) e ganho de peso médio diário (GPMD), nas comparações entre linhagens, sistema de criação e interação linhagem x sistema de criação. As diferenças significativas nos valores de consumo de ração (CR) e conversão alimentar (CA), foram observadas apenas nas comparações entre linhagens. A mortalidade não foi significativa em nenhuma das variáveis estudadas.

Os valores médios de idade 2300, GPMD, CR, CA e mortalidade das linhagens, sistema e criação e das interações linhagem x sistema de criação, estão apresentados nas Tabelas 3, 4 e 5, respectivamente. 
Tabela 2. Análise de variância das variáveis estudadas.

\begin{tabular}{lcccccc}
\hline \multicolumn{1}{c}{ FV } & GL & Idade 2300 & GPMD & CR & CA & Mortalidade \\
\hline Linhagem (L) & 3 & $972,541^{* *}$ & $193,478^{* *}$ & $2.686 .347 * *$ & $0,500^{* *}$ & $9,031 \mathrm{~ns}$ \\
Erro (a) & 12 & 1,354 & 0,212 & 53.181 & 0,010 & 2,968 \\
Sistema (Si) & 1 & $21,125^{* *}$ & $2,220^{*}$ & $6.881 \mathrm{~ns}$ & $0,0009 \mathrm{~ns}$ & $3,281 \mathrm{~ns}$ \\
L x Si & 3 & $17,708^{* *}$ & $2,238^{* *}$ & $24.552 \mathrm{~ns}$ & $0,003 \mathrm{~ns}$ & $3,281 \mathrm{~ns}$ \\
Resíduo & 12 & 0,729 & 0,257 & 91.734 & 0,016 & 46,625 \\
\hline CV $(\%)$ & $\begin{array}{c}1,21 \\
* *\end{array}<0,01 ; * \mathrm{p}<0,05 ;$ ns $=$ não significativo & & & & \\
\end{tabular}

\subsubsection{Efeito da linhagem}

As aves das linhagens Label Rouge (LR) e Caipirinha (CP) apresentaram maior tempo para atingir à idade 2300, diferindo-se significativamente $(\mathrm{P}<0,01) \quad 7,25$ dias entre si e 22,63 e 15,38 dias em relação à Paraíso Pedrês (PP), respectivamente. As linhagens PP e 7P apresentaram as menores idades 2300, porém não apresentaram diferenças significativas entre si (Tabela 3 ).

Ao comparar o GPMD entre as linhagens, verificou-se que não houve diferença entre as linhagens PP e 7P, porém, entre LR e CP foi observado uma diferença significativa $(\mathrm{P}<0,01)$ de 9,32 \% e, as aves da linhagem PP apresentaram um aumento significativo $(\mathrm{P}<0,01)$, de 20,12\% e $26,78 \%$ em relação as linhagens CP e LR, respectivamente (Tabela 3 ).

Silva (2001) afirma que a avaliação e o desenvolvimento de materiais genéticos especializados, "Frango Tipo Caipira", são de extrema importância para programas de melhoramento genético animal. As linhagens PP e 7P são consideradas linhagens de crescimento rápido, enquanto que $\mathrm{LR}$ e $\mathrm{CP}$ são de crescimento lento, 
portanto, os valores encontrados confirmam os resultados esperados entre as linhagens em relação à velocidade de ganho de peso.

Analisando os resultados encontrados e as exigências do Ofício Circular DIPOA No 007/99, que diz que as aves “Tipo Caipira” devem ser criadas por um período mínimo de 85 dias, a linhagem LR foi a que atendeu melhor as recomendações devido ao fato de terem sido levados 83,5 dias para atingir o peso médio estipulado de 2300 g. A segunda linhagem que se aproximou das recomendações foi a CP, com um período de 76,25 dias, seguindo de 7P e PP que levaram 62,12 e 60,87 dias, respectivamente.

$\mathrm{O}$ menor consumo de ração foi verificado nas linhagem $7 \mathrm{P}$, enquanto que o maior foi na linhagem LR (Tabela 3). As médias entre as linhagens CP e PP não diferiram significativamente $(\mathrm{P}>0,05)$, porém, ambas apresentaram um aumento significativo $(\mathrm{P}<0,01)$, no valor de 692 g e 434 g ou 16,08\% e 10,08\%, respectivamente, em relação à linhagem 7P. A linhagem LR apresentou um aumento de 32,16\% no consumo de ração $(\mathrm{P}<0,01)$, em relação à linhagem 7P (Tabela 3).

Em relação aos resultados de conversão alimentar, verificou-se que a linhagem 7P apresentou os melhores resultados, enquanto que o pior ficou com a linhagem LR (Tabela 3). Não houve diferença significativa $(\mathrm{P}>0,05)$ entre as linhagens CP e PP, nem entre PP e 7P (Tabela 3). Contudo, as aves das linhagens CP e LR apresentaram os piores resultados de $\mathrm{CA}(\mathrm{P}<0,01)$, em relação à linhagem $7 \mathrm{P}$, da ordem de $16,0 \%$ e $31,5 \%$, respectivamente (Tabela 3 ).

Carrijo et al. (2001), ao avaliarem linhagens alternativas na criação de frango tipo caipira, encontraram diferenças significativas $(\mathrm{P}<0,05)$ entre linhagens para consumo de ração, porém não verificaram diferenças significativas entre linhagens para conversão alimentar.

As diferenças em relação à aptidão e ao desempenho de linhagens comerciais de frangos tipo caipira são grandes, comparadas às linhagens industriais existentes (Figueiredo, 2001).

Isto explica, em parte, as diferenças de desempenho produtivo encontrado entre as linhagens comerciais de frangos tipo caipira, além do fato dessas linhagens 
estarem há pouco tempo no mercado e também pela pequena quantidade de trabalhos realizados nesta área.

Similarmente aos resultados de diferenças entre linhagens tipo caipira para consumo de ração, foram observadas diferenças significativas entre linhagens comerciais nos trabalhos realizados por Garcia et al.(1991); Garcia et al. (1992); Mizubuti et al. (1994); Souza et al. (1994) e Lisboa (1995). Entretanto, Ávila et al. (1992), Politi et al. (1994); Abreu et al. (1996a) e Mendes et al. (1994) não encontraram diferenças significativas entre linhagens para consumo de ração.

Em relação ao efeito significativo entre linhagens de frango tipo caipira ou colonial para conversão alimentar, Figueiredo (2001) também encontrou diferenças entre linhagens disponíveis no mercado brasileiro.

Resultados semelhantes de diferenças entre linhagens tipo caipira, para conversão alimentar, foram encontrados em linhagens comerciais por Garcia et al. (1992); Souza et al. (1994) e Ávila et al. (1994). Porém, Garcia et al. (1991); Mendes et al. (1994); Politi et al. (1994); Mizubuti et al. (1994), Lisboa (1995) e Abreu et al. (1996) não encontraram diferenças significativas entre linhagens para conversão alimentar.

A mortalidade de todas as linhagens foi bastante baixa variando de 0,62 a $2,75 \%$, não diferindo entre si $(\mathrm{P}>0,05)$. 
Tabela 3. Médias das linhagens para as variáveis idade aos 2300g (Idade 2300), ganho de peso médio diário (GPMD), consumo de ração (CR), conversão alimentar (CA) e mortalidade.

\begin{tabular}{lccccc}
\hline \multicolumn{1}{c}{ Linhagem } & $\begin{array}{c}\text { Idade } 2300^{1} \\
(\text { dias })\end{array}$ & $\begin{array}{c}\text { GPMD } \\
(\mathrm{g})\end{array}$ & $\begin{array}{c}\mathrm{CR}^{\mathrm{I}} \\
(\mathrm{g})\end{array}$ & $\mathrm{CA}^{\mathrm{I}}$ & $\begin{array}{c}\text { Mortalidade } \\
\end{array}$ \\
\hline Label Rouge & $83,50 \mathrm{a}$ & $27,05 \mathrm{c}$ & $5.688 \mathrm{a}$ & $2,46 \mathrm{a}$ & $0,62 \mathrm{a}$ \\
Caipirinha & $76,25 \mathrm{~b}$ & $29,83 \mathrm{~b}$ & $4.996 \mathrm{~b}$ & $2,17 \mathrm{~b}$ & $2,75 \mathrm{a}$ \\
$7 \mathrm{P}$ & $62,12 \mathrm{c}$ & $36,37 \mathrm{a}$ & $4.304 \mathrm{c}$ & $1,87 \mathrm{c}$ & $0.87 \mathrm{a}$ \\
Paraíso Pedrês & $60,87 \mathrm{c}$ & $37,05 \mathrm{a}$ & $4.738 \mathrm{~b}$ & $2,06 \mathrm{cb}$ & $2,37 \mathrm{a}$ \\
\hline
\end{tabular}

1 = Médias seguidas de letras diferentes na coluna diferem estatisticamente pelo teste de Tukey $(\mathrm{p}<0,01)$

\subsubsection{Efeito do sistema de criação}

Com relação aos sistemas de criação, observou-se efeito significativo $(\mathrm{P}<0,01)$, na idade 2300, sendo que as aves do sistema intensivo foram 1,63 dias mais precoce que as aves no sistema semi-intensivo (Tabela 4).

Entre os sistemas de criação, verificou-se um aumento significativo $(\mathrm{P}<0,05)$, de $0,53 \mathrm{~g}$ ou $1,61 \%$ no GPMD para o sistema intensivo de criação em relação ao sistema semi-intensivo (Tabela 4).

Apesar de ter sido pequena a diferença do GPMD entre os sistema de criação, quando comparadas as diferença entre linhagens dentro de cada um dos sistemas de criação foram encontradas diferenças maiores.

Comparando as idades 2300 dos dois sistemas de criação em relação à exigência de 85 dias do Ofício Circular DIPOA No 007/99, verifica-se uma diferença de 15,13 e 13,50 dias, para os sistemas intensivo e semi-intensivo, respectivamente. Esses resultados, comparados ao GPMD encontrado, demonstram que as aves criadas nos diferentes sistemas tem a potencial para atingir um peso maior se forem criadas até os 85 
dias, no entanto se faz necessário avaliar se esse aumento esperado no peso final é realmente desejado para esses materiais genéticos.

Não foram encontradas diferenças significativas $(\mathrm{P}>0,05)$ de sistema de criação para as variáveis consumo de ração, conversão alimentar e mortalidade.

Tabela 4. Médias dos sistemas intensivo e semi-intensivo de criação para as variáveis idade aos 2300g (Idade 2300), ganho de peso médio diário (GPMD), consumo de ração (CR), conversão alimentar (CA) e mortalidade.

\begin{tabular}{lccccc}
\hline \multicolumn{1}{c}{ Sistema } & $\begin{array}{c}\text { Idade } 2300^{1} \\
(\text { dias })\end{array}$ & $\begin{array}{c}\text { GPMD }^{2} \\
(\mathrm{~g})\end{array}$ & $\begin{array}{c}\text { CR } \\
(\mathrm{g})\end{array}$ & CA & $\begin{array}{c}\text { Mortalidade } \\
(\%)\end{array}$ \\
\hline Intensivo & $69,87 \mathrm{~b}$ & $32,94 \mathrm{a}$ & $4.917 \mathrm{a}$ & $2,13 \mathrm{a}$ & $1,68 \mathrm{a}$ \\
Semi-intensivo & $71,50 \mathrm{a}$ & $32,26 \mathrm{~b}$ & $4.946 \mathrm{a}$ & $2,14 \mathrm{a}$ & $1,62 \mathrm{a}$ \\
\hline
\end{tabular}

Médias seguidas de letras diferentes na coluna diferem estatisticamente pelo teste de

Tukey $\left({ }^{1} \mathrm{p}<0,01\right)$ e $\left({ }^{2} \mathrm{p}<0,05\right)$

\subsubsection{Linhagem e sistema de criação.}

\subsubsection{Idade 2300}

Observou-se efeito significativo da interação linhagem $\mathrm{x}$ sistema de criação para idade $2300(\mathrm{P}<0,01)$. A ordem de manifestação das linhagens tanto no sistema intensivo quanto no semi-intensivo de criação não foi alterada, permanecendo na ordem de linhagem mais tardia para mais precoce: LR, CP, 7P e PP, respectivamente. A magnitude da variação de idade 2300 entre as linhagens $7 \mathrm{P}$ e $\mathrm{CP}$ foi 11 dias quando as aves foram criadas no sistema intensivo, enquanto que essa magnitude foi de 17,25 dias no sistema semi-intensivo. Já para as linhagens CP e LR a magnitude de variação foi de 9,75 dias quando as aves foram criadas no sistema intensivo e de 4,75 dias quando criadas no sistema semi-intensivo (Figura 1). 
A linhagem $\mathrm{CP}$ foi a única que apresentou diferença significativa da idade 2300 entre sistemas, sendo que o sistema semi-intensivo de criação demorou 6 dias a mais para atingir o peso final do que no sistema intensivo (79,25 e 73,25 dias, respectivamente), ao passo que não ocorreram diferenças significativas para as outras linhagens (Tabela 5).

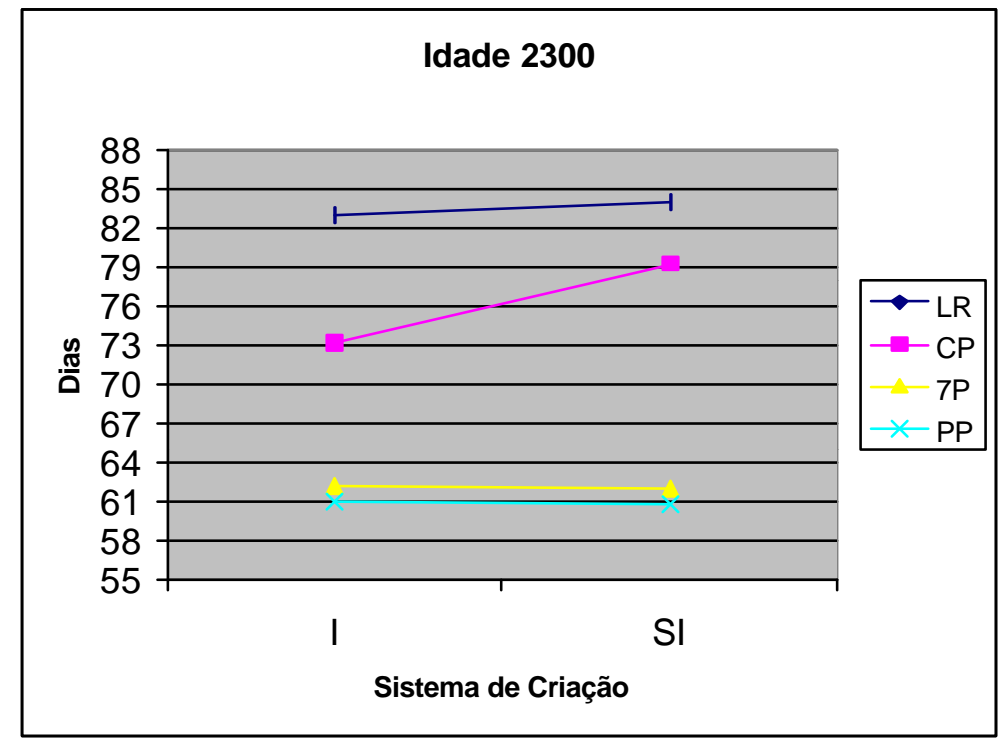

Figura 1 - Interação linhagem x sistema de criação para variável idade 2300.

Nesse período 6 dias maior da linhagem CP no sistema semi-intensivo, não houve aumento no consumo total de ração, indicando que o consumo diário foi mais baixo provavelmente em razão de permanecer mais tempo no pasto. Como as conversões alimentares não diferiram, é possível que a pastagem tenha fornecido as condições para que não fosse necessário um consumo maior de ração para compensar o dispêndio de energia durante o período de pastoreio. 
Tabela 5. Média das linhagens para as características idade 2300, ganho de peso médio diário (GPMD), consumo de ração (CR), conversão alimentar (CA) e mortalidade (Mort.), nos diferentes sistemas de criação.

\begin{tabular}{lccccc}
\hline \multirow{2}{*}{ Característica } & \multirow{2}{*}{ Sistema } & LR & CP & $7 P$ & PP \\
\hline \multirow{2}{*}{ Idade 2300 } & Intensivo & $83,00 \mathrm{aA}$ & $73,25 \mathrm{bB}$ & $62,25 \mathrm{cA}$ & $61,00 \mathrm{cA}$ \\
& Semi-intensivo & $84,00 \mathrm{aA}$ & $79,25 \mathrm{bA}$ & $62,00 \mathrm{cA}$ & $60,75 \mathrm{cA}$ \\
GPMD & Intensivo & $27,85 \mathrm{cA}$ & $31,25 \mathrm{bA}$ & $36,99 \mathrm{aA}$ & $37,75 \mathrm{aA}$ \\
& Semi-intensivo & $27,53 \mathrm{cA}$ & $29,17 \mathrm{bB}$ & $37,13 \mathrm{aA}$ & $37,90 \mathrm{aA}$ \\
$\mathrm{CR}$ & Intensivo & $5.594 \mathrm{aA}$ & $5.002 \mathrm{abA}$ & $4.300 \mathrm{bA}$ & $4.771 \mathrm{bA}$ \\
& Semi-intensivo & $5.782 \mathrm{aA}$ & $4990 \mathrm{bcA}$ & $4.308 \mathrm{cA}$ & $4.704 \mathrm{cA}$ \\
$\mathrm{CA}$ & Intensivo & $2,43 \mathrm{aA}$ & $2,17 \mathrm{abA}$ & $1,86 \mathrm{bA}$ & $2,07 \mathrm{bA}$ \\
& Semi-intensivo & $2,50 \mathrm{aA}$ & $2,17 \mathrm{bA}$ & $1,87 \mathrm{bA}$ & $2,04 \mathrm{bA}$ \\
Mort. & Intensivo & $0,75 \mathrm{aA}$ & $3,00 \mathrm{aA}$ & $1,50 \mathrm{aA}$ & $1,50 \mathrm{aA}$ \\
& Semi-intensivo & $0,50 \mathrm{aA}$ & $2,50 \mathrm{aA}$ & $0,25 \mathrm{aA}$ & $3,25 \mathrm{aA}$ \\
\hline a, $\mathrm{b}=$ letras minúsculas comparam médias na mesma linha para cada característica, \\
dentro de cada sistema $(\mathrm{P}<0,01)$
\end{tabular}

$\mathrm{A}, \mathrm{B}=$ letras maiúsculas comparam médias na mesma coluna para cada característica, entre cada sistema $(\mathrm{p}<0,01)$

\subsubsection{Ganho de peso médio diário (GPMD)}

Foi observado efeito significativo da interação linhagem $x$ sistema de criação para GPMD $(\mathrm{P}<0,01)$. A ordem de manifestação das linhagens tanto no sistema intensivo quanto no semi-intensivo de criação não foi alterada, permanecendo na ordem de linhagem mais precoce para mais tardia: PP, 7P, CP e LR, respectivamente.

A magnitude da variação de GPMD entre as linhagens 7P e CP foi 7,96 g quando as aves foram criadas no sistema intensivo, enquanto que essa magnitude foi de 5,74 g no sistema semi-intensivo. Já para as linhagens CP e LR a magnitude de variação foi de 3,43 $\mathrm{g}$ quando as aves foram criadas no sistema intensivo e de 1,64 $\mathrm{g}$ dias quando criadas no sistema semi-intensivo (Figura 2). 
A linhagem $\mathrm{CP}$ foi a única que apresentou diferença significativa no GPMD entre sistemas, sendo que o sistema intensivo de criação teve um aumento de $2,08 \mathrm{~g}$ ou $6,74 \%$, em relação ao sistema semi-intensivo. Não ocorreram diferenças significativas para as outras linhagens (Tabela 5).

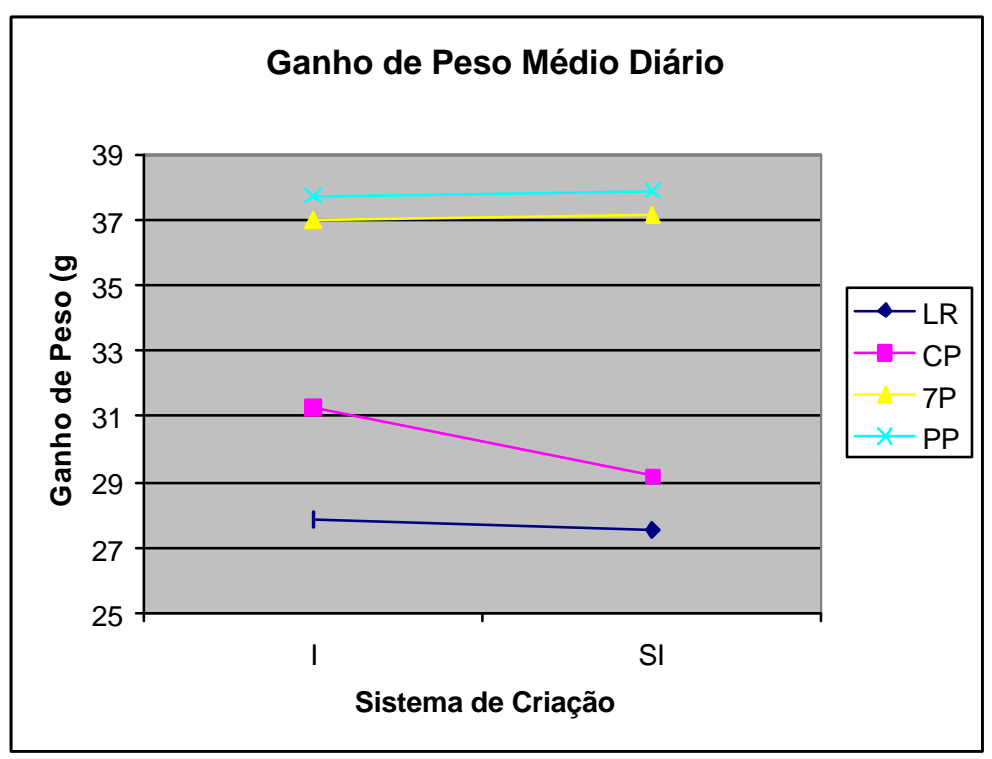

Figura 2 - Interação linhagem x sistema de criação para a variável ganho de peso médio diário.

A diminuição de $6,74 \%$ no GPMD da linhagem CP no sistema semiintensivo indica que as aves tiveram um maior dispêndio de energia durante o período de pastoreio ou de permanência no pasto, em relação ao sistema intensivo. Estes resultados vêm corroborar com o trabalho de Silva (2001), que ao avaliar a taxa de permanência no pasto das mesmas linhagens utilizadas no referido estudo, encontrou diferença significativa entre as linhagens, sendo $\mathrm{CP}$ uma das linhagens com maior tempo de permanência no pasto. 


\subsubsection{Consumo de ração $(\mathrm{CR})$}

Não foi encontrada interação significativa entre linhagem e sistema de criação para conversão alimentar. Porém, no sistema intensivo de criação, as linhagens LR e CP não diferiram significativamente $(P>0,05)$, em relação ao consumo de ração e nem as linhagens CP, 7P e PP. Entretanto, o maior consumo ficou com a linhagem LR e o menor com a linhagem $\mathbb{P}$, com diferença significativa $(\mathrm{P}<0,01)$, de $1.294 \mathrm{~g}$ ou $30,09 \%$ a mais para a linhagem LR em relação a 7P (Tabela 5).

Com relação ao sistema semi-intensivo de criação, as linhagens $\mathrm{CP}, 7 \mathrm{P}$ e PP não diferiram significativamente $(\mathrm{P}>0,05)$, entre si, em relação ao consumo de ração. Porém, com relação ao maior e menor consumo, as linhagens comportaram-se como no sistema intensivo e, os valores foram de $1.474 \mathrm{~g}$ ou $34,21 \%$ a mais de consumo de ração para a linhagem LR em relação a 7P (Tabela 5).

\subsubsection{Conversão alime ntar (CA)}

Em relação à conversão alimentar, não foi encontrada interação significativa entre linhagem e sistema de criação. Entretanto, ao avaliar apenas o sistema intensivo de criação, as linhagens LR e CP e as linhagens 7P e PP não diferiram significativamente $(\mathrm{P}>0,05)$ em relação à conversão alimentar. A linhagem LR apresentou a pior conversão alimentar e 7P a melhor, com diferença de 0,57 ou 30,64\% entre as linhagens (Tabela 5).

No sistema semi-intensivo de criação, as linhagens $\mathrm{CP}, 7 \mathrm{P}$ e PP não diferiram significativamente $(\mathrm{P}>0,05)$ em relação à conversão alimentar. A linhagem LR apresentou diferença significativa $(\mathrm{P}<0,01)$ em relação as demais linhagens, verificandose uma diferença de 0,63 ou 33,69\% em relação a linhagem 7P que apresentou a melhor conversão alimentar (Tabela 5). 


\subsection{Rendimento de carcaça}

Como se buscava comparar o rendimento de carcaça das aves pesando cerca de $2300 \mathrm{~g}$ de peso vivo, foram realizados abates com, 60,75; 61,00;62,00;62,25; 73,25; 79,25; 83,00; 84,00 dias de idade, para os tratamentos T8, T7, T6, T5, T3, T4, T1 e T2, respectivamente. Entretanto, devido à idade de abate das aves para atingir o peso de $2300 \mathrm{~g}$ ter sido calculado com base na diferença de ganho de peso médio diário entre as linhagens, os tratamentos T8 e T7, T6 e T5, T3, T4, T1 e T2, foram para o abate com 60,$87 ; 62,12 ; 73,25 ; 79,25$ e 83,5 dias de idade, respectivamente, totalizando 5 abates.

Os efeitos significativos de linhagem, sistema de criação, sexo e das interações linhagem x sistema de criação e linhagem x sexo, sobre o rendimento das partes principais e secundárias da carcaça, em relação ao peso vivo de plataforma, de frangos de corte tipo caipira, estão apresentados através das análises de variância das variáveis das carcaças (Tabelas 6, 7 e 8).

Os resultados observados mostraram diferenças significativas entre as linhagens para as variáveis asa (Tabela 6), carne de peito, osso de perna, osso de peito e pele de peito (Tabela 7), gordura abdominal (Tabela 8).

Em relação aos diferentes sistemas de criação, foram observadas diferenças significativas apenas para a variável dorso (Tabela 6).

Levando-se em consideração o sexo, foram encontradas diferenças significativas para as variáveis pernas, asa e peito (Tabela 6), carne de pernas, carne de peito, osso das pernas, pele de peito (Tabela 7), gordura abdominal, vísceras e pés (Tabela 7).

Apenas a variável carne de peito (Tabela 7) mostrou efeito da interação linhagem x sistema de criação e, as variáveis asa (Tabela 6) e pés (Tabela 8) sofreram interação linhagem x sexo. 
Tabela 6. Análise de variância das variáveis das carcaças estudadas.

\begin{tabular}{|c|c|c|c|c|c|c|}
\hline \multirow{3}{*}{ FV } & \multirow{3}{*}{ GL } & \multicolumn{5}{|c|}{ Quadrado Médio } \\
\hline & & Carcaça & Pernas & Asa & Peito & Dorso \\
\hline & & \multicolumn{5}{|l|}{ Eviscerada } \\
\hline Linhagem (L) & 3 & $9,03 \times 10^{-4} \mathrm{~ns}$ & $1,254 \times 10^{-4} \mathrm{~ns}$ & $0,57 \times 10^{-4} * *$ & $4,48 \times 10^{-4} \mathrm{~ns}$ & $2,51 \times 10^{-4} \mathrm{~ns}$ \\
\hline erro (a) & 3 & $11,24 \times 10^{-4}$ & $2,63 \times 10^{-4}$ & $0,03 \times 10^{-4}$ & $0,76 \times 10^{-4}$ & $0,55 \times 10^{-4}$ \\
\hline Sistema $(\mathrm{Si})$ & 1 & $0,014 \times 10^{-4} \mathrm{~ns}$ & $1,12 \times 10^{-4} \mathrm{~ns}$ & $0,015 \times 10^{-4} \mathrm{~ns}$ & $0,12 \times 10^{-4} \mathrm{~ns}$ & $1,63 \times 10^{-4} *$ \\
\hline erro b & 1 & $11,55 \times 10^{-4}$ & $0,0004 \times 10^{-4}$ & $0,0054 \times 10^{-4}$ & $1,16 \times 10^{-4}$ & $0,001 \times 10^{-4}$ \\
\hline $\mathrm{L} \times \mathrm{Si}$ & 3 & $4,41 \times 10^{-4} \mathrm{~ns}$ & $0,96 \times 10^{-4} \mathrm{~ns}$ & $0,013 \times 10^{-4} \mathrm{~ns}$ & $0,33 \times 10^{-4} \mathrm{~ns}$ & $0,050 \times 10^{-4} \mathrm{~ns}$ \\
\hline Erro c & 24 & $8,13 \times 10^{-4}$ & $1,86 \times 10^{-4}$ & $0,09 \times 10^{-4}$ & $1,17 \times 10^{-4}$ & $0,301 \times 10^{-4}$ \\
\hline $\operatorname{Sexo}(\mathrm{S})$ & 1 & $3,10 \times 10^{-4} \mathrm{~ns}$ & $20,17 \times 10^{-4} * *$ & $0,32 \times 10^{-4} *$ & $22,71 \times 10^{-4} * *$ & $0,19 \times 10^{-4} \mathrm{~ns}$ \\
\hline $\mathrm{S} \times \mathrm{L}$ & 3 & $1,85 \times 10^{-4} \mathrm{~ns}$ & $1,46 \times 10^{-4} \mathrm{~ns}$ & $0,30 \times 10^{-4} *$ & $1,22 \times 10^{-4} \mathrm{~ns}$ & $1,17 \times 10^{-4} \mathrm{~ns}$ \\
\hline Resíduo & 24 & $6,09 \times 10^{-4}$ & $1,18 \times 10^{-4}$ & $0,074 \times 10^{-4}$ & $1,19 \times 10^{-4}$ & $0,42 \times 10^{-4}$ \\
\hline $\mathrm{CV}(\%)$ & & 3,66 & 4,70 & 3,16 & 5,35 & 4,11 \\
\hline
\end{tabular}


Tabela 7. Análise de variância das variáveis das carcaças estudadas.

\begin{tabular}{|c|c|c|c|c|c|c|c|}
\hline \multirow[b]{2}{*}{$\mathrm{FV}$} & \multirow[b]{2}{*}{ GL } & \multicolumn{6}{|c|}{ Quadrado Médio } \\
\hline & & $\begin{array}{c}\text { Carne das } \\
\text { Pernas }\end{array}$ & $\begin{array}{c}\text { Carne de } \\
\text { Peito }\end{array}$ & $\begin{array}{c}\text { Osso das } \\
\text { Pernas }\end{array}$ & $\begin{array}{c}\text { Osso de } \\
\text { Peito }\end{array}$ & $\begin{array}{c}\text { Pele das } \\
\text { Pernas }\end{array}$ & $\begin{array}{c}\text { Pele de } \\
\text { Peito }\end{array}$ \\
\hline Linhagem (L) & 3 & $2,59 \times 10^{-4} \mathrm{~ns}$ & $11,56 \times 10^{-4} *$ & $3,78 \times 10^{-4} *$ & $0,87 \times 10^{-4} * *$ & $1,52 \times 10^{-4} \mathrm{~ns}$ & $3,47 \times 10^{-4} *$ \\
\hline Erro (a) & 3 & $0,33 \times 10^{-4}$ & $0,710 \times 10^{-4}$ & $0,28 \times 10^{-4}$ & $0,02 \times 10^{-4}$ & $0,26 \times 10^{-4}$ & $0,15 \times 10^{-4}$ \\
\hline Sistema $(\mathrm{Si})$ & 1 & $0,30 \times 10^{-4} \mathrm{~ns}$ & $0,26 \times 10^{-4} \mathrm{~ns}$ & $0,37 \times 10^{-4} \mathrm{~ns}$ & $0,78 \times 10^{-4} \mathrm{~ns}$ & $0,05 \times 10^{-4} \mathrm{~ns}$ & $0,08 \times 10^{-4} \mathrm{~ns}$ \\
\hline Erro b & 1 & $0,050 \times 10^{-4}$ & $1,98 \times 10^{-4}$ & $0,19 \times 10^{-4}$ & $0,36 \times 10^{-4}$ & $1,16 \times 10^{-4}$ & $0,01 \times 10^{-4}$ \\
\hline $\mathrm{L} \times \mathrm{Si}$ & 3 & $0,61 \times 10^{-4} \mathrm{~ns}$ & $1,29 \times 10^{-4} *$ & $0,18 \times 10^{-4} \mathrm{~ns}$ & $0,06 \times 10^{-4} \mathrm{~ns}$ & $0,29 \times 10^{-4} \mathrm{~ns}$ & $0,18 \times 10^{-4} \mathrm{~ns}$ \\
\hline Erro c & 24 & $0,29 \times 10^{-4}$ & $0,38 \times 10^{-4}$ & $0,18 \times 10^{-4}$ & $0,06 \times 10^{-4}$ & $0,35 \times 10^{-4}$ & $0,07 \times 10^{-4}$ \\
\hline Sexo $(S)$ & 1 & $10,77 \times 10^{-4} * *$ & $13,90 \times 10^{-4} * *$ & $4,66 \times 10^{-4} * *$ & $0,002 \times 10^{-4} \mathrm{~ns}$ & $0,56 \times 10^{-4} \mathrm{~ns}$ & $1,50 \times 10^{-4} * *$ \\
\hline $\mathrm{S} \times \mathrm{L}$ & 3 & $0,273 \times 10^{-4} \mathrm{~ns}$ & $1,57 \times 10^{-4} \mathrm{~ns}$ & $0,34 \times 10^{-4} \mathrm{~ns}$ & $0,27 \times 10^{-4} \mathrm{~ns}$ & $0,24 \times 10^{-4} \mathrm{~ns}$ & $0,06 \times 10^{-4} \mathrm{~ns}$ \\
\hline Resíduo & 24 & $0,253 \times 10^{-4}$ & $0,75 \times 10^{-4}$ & $0,14 \times 10^{-4}$ & $0,11 \times 10^{-4}$ & $0,31 \times 10^{-4}$ & $0,06 \times 10^{-4}$ \\
\hline $\mathrm{CV}(\%)$ & & 6 & 6,16 & 7,10 & 8,62 & 20,48 & 10,03 \\
\hline
\end{tabular}


Tabela 8. Análise de variância das variáveis das carcaças estudadas.

\begin{tabular}{|c|c|c|c|c|c|}
\hline \multirow[b]{2}{*}{$\mathrm{FV}$} & \multirow[b]{2}{*}{ GL } & \multicolumn{4}{|c|}{ Quadrado Médio } \\
\hline & & Gordura Abdominal & Vísceras & Pés & Cabeça e Pescoço \\
\hline Linhagem (L) & 3 & $2,57 \times 10^{-4} * *$ & $1,69 \times 10^{-4} \mathrm{~ns}$ & $0,23 \times 10^{-4} \mathrm{~ns}$ & $2,07 \times 10^{-4} \mathrm{~ns}$ \\
\hline Erro (a) & 3 & $0,073 \times 10^{-4}$ & $0,42 \times 10^{-4}$ & $0,12 \times 10^{-4}$ & $0,025 \times 10^{-4}$ \\
\hline Sistema $(\mathrm{Si})$ & 1 & $0,16 \times 10^{-4} \mathrm{~ns}$ & $0,17 \times 10^{-4} \mathrm{~ns}$ & $0,18 \times 10^{-4} \mathrm{~ns}$ & $0,069 \times 10^{-4} \mathrm{~ns}$ \\
\hline Erro b & 1 & $0,63 \times 10^{-4}$ & $0,02 \times 10^{-4}$ & $0,09 \times 10^{-4}$ & $0,78 \times 10^{-4}$ \\
\hline $\mathrm{L} \times \mathrm{Si}$ & 3 & $0,17 \times 10^{-4} \mathrm{~ns}$ & $0,90 \times 10^{-4} \mathrm{~ns}$ & $0,27 \times 10^{-4} \mathrm{~ns}$ & $0,49 \times 10^{-4} \mathrm{~ns}$ \\
\hline Erro c & 24 & $0,24 \times 10^{-4}$ & $0,560 \times 10^{-4}$ & $0,07 \times 10^{-4}$ & $0,18 \times 10^{-4}$ \\
\hline $\operatorname{Sexo}(S)$ & 1 & $12,47 \times 10^{-4} * *$ & $1,95 \times 10^{-4} *$ & $10,03 \times 10^{-4} * *$ & $3,20 \times 10^{-4} \mathrm{~ns}$ \\
\hline $\mathrm{S} \times \mathrm{L}$ & 3 & $0,70 \times 10^{-4} \mathrm{~ns}$ & $0,48 \times 10^{-4} \mathrm{~ns}$ & $0,19 \times 10^{-4} *$ & $0,49 \times 10^{-4} \mathrm{~ns}$ \\
\hline Resíduo & 24 & $0,28 \times 10^{-4}$ & $0,45 \times 10^{-4}$ & $0,052 \times 10^{-4}$ & $0,078 \times 10^{-4}$ \\
\hline $\mathrm{CV}(\%)$ & & 17,09 & 6,66 & 6,12 & 4,10 \\
\hline
\end{tabular}


A comparação entre as médias das linhagens, dos sistemas de criação e dos sexos para as variáveis das partes principais da carcaça estão nas Tabelas 9, 10 e 11, respectivamente. Entretanto, para o rendimento das partes secundárias da carcaça, estão nas Tabelas 12, 13 e 14, respectivamente.

\subsubsection{Rendimento das partes principais da carcaça}

\subsubsection{Efeito da linhagem}

Os resultados das médias das linhagens em relação ao rendimento das partes principais da carcaça, estão apresentados na Tabela 9. Para as variáveis carcaça eviscerada, pernas, peito, dorso e carne das pernas, não foram encontradas diferenças significativas $(\mathrm{P}>0,05)$, entre as linhagens.

Quanto ao rendimento das partes principais da carcaça (Tabela 9), encontrou-se efeito significativo da média das linhagens para percentagem de asa $(\mathrm{P}<0,01)$ e para percentagem de carne de peito $(\mathrm{P}<0,05)$.

As aves da linhagem LR apresentaram a maior percentagem de asa, diferindo significativamente $(\mathrm{P}<0,05)$ 4,28\%, 4,62\% e 3,72\%, respectivamente, em relação as linhagens $\mathrm{CP}, 7 \mathrm{P}$ e $\mathrm{PP}$, que por sua vez, não diferiram entre si $(\mathrm{P}>0,05)$.

As diferenças observadas no rendimento de percentagem de asas entre linhagens de frango tipo caipira, concordam os resultados observados entre linhagens industriais realizados por Politi et al. (1993) e Politi et al. (1994) e diferem daqueles observados por Mendes (1990), Garcia et al. (1991), Mendes et al. (1993) e Mendes et al. (1994).

Analisando-se a carne de peito, a linhagem LR diferiu-se significativamente $(\mathrm{P}<0,01)$, em relação as linhagens $7 \mathrm{P}$ e $\mathrm{CP}$, apresentando valores de rendimento $11,75 \%$ e $11,55 \%$ maior, respectivamente.

Não foram encontradas diferenças significativas $(\mathrm{P}>0,05)$ entre as linhagens LR e PP para percentagem de carne de peito. Entretanto, analisando a idade de abate das aves das linhagens LR (83,5 dias) e PP (60,87 dias), esses resultados 
discordam dos encontrados por Mendes (1990), que ao avaliar o efeito da idade de abate de frangos de linhagens de corte industrial sobre o rendimento de carcaça e das partes em relação ao peso vivo, não encontrou diferença da idade de abate para percentagem de carne de peito nas aves abatidas com 48 e 53 dias de idade. Porém, ao avaliar o efeito da idade de abate sobre o rendimento de carcaça e das partes em relação ao peso da carcaça eviscerada, esse autor encontrou diferenças significativas $(\mathrm{P}<0,05)$ para percentagem de carne de peito $(\mathrm{P}<0,05)$ para as aves abatidas aos 48 dias de idade em relação as aves abatidas aos 53 dias de idade.

Figueiredo (2001) apresenta diferenças entre linhagens comerciais de frango tipo caipira para produção de peito. Estes dados diferem dos resultados deste estudo que não verificou diferenças entre linhagens para percentagem de rendimento de peito. No entanto foram encontradas diferenças para percentagem de carne peito.

Comparando o efeito significativo da linhagem de frango de corte tipo caipira para percentagem de rendimento de carne peito, em relação à linhagens de fr ango de corte industriais, os resultados encontrados são semelhantes aos observados por Politi et al. (1993), Politi et al. (1994), Souza et al.(1994), entretanto diferem de Mendes et al. (1993a).

O rendimento de carne de peito é de grande importância para o mercado consumidor atual, resultando em uma maior remuneração entre os diferentes cortes das carcaças de frangos de corte industrial.

Nos dias de hoje, o frango tipo caipira é vendido inteiro no mercado, porém, possíveis mudanças no mercado consumidor podem ocorrer e exigir um maior rendimento de carne de peito. Com base nos resultados apresentados neste estudo, as linhagens LR e PP seriam as que melhor atenderiam as exigências de maior percentagem de carne de peito. 
Tabela 9. Comparação entre médias das linhagens Label Rouge (LR), Caipirinha (CP), 7P e Paraíso Pedrês (PP), para as variáveis rendimento das partes principais da carcaça.

\begin{tabular}{lcccc}
\hline \multirow{2}{*}{ Características } & \multicolumn{4}{c}{ LINHAGEM } \\
& LR & CP & $7 P$ & PP \\
\hline Carcaça eviscerada (\%) & $68,11 \mathrm{a}$ & $67,30 \mathrm{a}$ & $67,62 \mathrm{a}$ & $66,33 \mathrm{a}$ \\
Pernas (\%) & $23,15 \mathrm{a}$ & $22,93 \mathrm{a}$ & $23,41 \mathrm{a}$ & $22,76 \mathrm{a}$ \\
Asa (\%) 1 & $8,88 \mathrm{a}$ & $8,50 \mathrm{~b}$ & $8,47 \mathrm{~b}$ & $8,55 \mathrm{~b}$ \\
Peito (\%) & $20,61 \mathrm{a}$ & $19,77 \mathrm{a}$ & $20,23 \mathrm{a}$ & $21,02 \mathrm{a}$ \\
Dorso (\%) & $15,35 \mathrm{a}$ & $15,76 \mathrm{a}$ & $15,51 \mathrm{a}$ & $16,26 \mathrm{a}$ \\
Carne de perna (\%) & $15,31 \mathrm{a}$ & $15,12 \mathrm{a}$ & $15,01 \mathrm{a}$ & $14,38 \mathrm{a}$ \\
Carne de peito $(\%)^{2}$ & $15,32 \mathrm{a}$ & $13,55 \mathrm{~b}$ & $13,52 \mathrm{~b}$ & $13,89 \mathrm{ab}$ \\
\hline
\end{tabular}

$\mathrm{a}, \mathrm{b}=$ letras minúsculas comparam médias na mesma linha para cada característica,

pelo teste de Tukey $\left({ }^{1} \mathrm{p}<0,01\right)$ e $\left({ }^{2} \mathrm{p}<0,05\right)$

\subsubsection{Efeito do sistema de criação}

Os resultados das médias dos sistemas de criação em relação ao rendimento das partes principais da carcaça estão apresentados na Tabela 10. Foram encontradas diferenças significativas $(\mathrm{P}<0,05)$ apenas para percentagem de dorso. As aves criadas no sistema intensivo apresentaram rendimento 2,06 \% maior que o sistema semi-intensivo.

Para as demais variáveis das partes principais da carcaça, os resultados mostraram que as aves criadas tanto no sistema intensivo quanto no sistema semiintensivo obtiveram os mesmos rendimentos, não diferindo significativamente $(\mathrm{P}>0,05)$. 
Tabela 10. Comparação entre médias das linhagens Label Rouge (LR), Caipirinha (CP), 7P e Paraíso Pedrês (PP), para as variáveis de rendimento das partes principais da carcaça, nos sistemas intensivo (I) e semi intensivo (SI) de criação de criação.

\begin{tabular}{|c|c|c|c|c|c|c|}
\hline \multirow[b]{2}{*}{ Característica } & \multirow[b]{2}{*}{ Sistema } & \multicolumn{4}{|c|}{ LINHAGEM } & \multirow{2}{*}{ Média } \\
\hline & & LR & $\mathrm{CP}$ & $7 \mathrm{P}$ & PP & \\
\hline \multirow{2}{*}{$\begin{array}{l}\text { Carcaça } \\
\text { eviscerada }(\%)\end{array}$} & $\overline{\mathrm{I}}$ & $68,39 \mathrm{aA}$ & $67,45 \mathrm{aA}$ & $67,92 \mathrm{aA}$ & $65,53 \mathrm{aA}$ & $67,32 \mathrm{~A}$ \\
\hline & SI & $67,83 \mathrm{aA}$ & $67,15 \mathrm{aA}$ & $67,32 \mathrm{aA}$ & $67,12 \mathrm{aA}$ & $67,26 \mathrm{~A}$ \\
\hline \multirow[t]{2}{*}{ Pernas (\%) } & I & $23,32 \mathrm{aA}$ & 23,35 aA & $22,67 \mathrm{aA}$ & $22,37 \mathrm{aA}$ & $22,93 \mathrm{~A}$ \\
\hline & SI & $22,98 \mathrm{aA}$ & 23,46 aA & 23,19 aA & $23,15 \mathrm{aA}$ & $23,19 \mathrm{~A}$ \\
\hline \multirow[t]{2}{*}{ Asa (\%) } & $\mathrm{I}$ & $8,92 \mathrm{aA}$ & 8,54 aA & $8,45 \mathrm{aA}$ & $8,56 \mathrm{aA}$ & $8,26 \mathrm{~A}$ \\
\hline & SI & $8,84 \mathrm{aA}$ & $8,47 \mathrm{aA}$ & $8,50 \mathrm{aA}$ & $8,55 \mathrm{aA}$ & $8,59 \mathrm{~A}$ \\
\hline \multirow[t]{2}{*}{ Peito (\%) } & I & $20,38 \mathrm{aA}$ & $19,69 \mathrm{aA}$ & $20,29 \mathrm{aA}$ & $21,10 \mathrm{aA}$ & $20,36 \mathrm{~A}$ \\
\hline & SI & $20,83 \mathrm{aA}$ & $19,86 \mathrm{aA}$ & $20,18 \mathrm{aA}$ & $20,93 \mathrm{aA}$ & $20,45 \mathrm{~A}$ \\
\hline \multirow[t]{2}{*}{ Dorso (\%) } & I & $15,58 \mathrm{aA}$ & $15,87 \mathrm{aA}$ & $15,64 \mathrm{aA}$ & $16,43 \mathrm{aA}$ & $15,88 \mathrm{~A}$ \\
\hline & SI & $15,12 \mathrm{bA}$ & $15,65 \mathrm{abA}$ & $15,39 \mathrm{abA}$ & $16,08 \mathrm{aA}$ & $15,56 \mathrm{~B}$ \\
\hline \multirow{2}{*}{$\begin{array}{l}\text { Carne de } \\
\text { Perna }(\%)\end{array}$} & I & $15,19 \mathrm{aA}$ & $14,85 \mathrm{aA}$ & $14,94 \mathrm{aA}$ & $14,58 \mathrm{aA}$ & $14,89 \mathrm{~A}$ \\
\hline & SI & $15,44 \mathrm{aA}$ & $15,39 \mathrm{aA}$ & $15,09 \mathrm{aA}$ & $14,19 \mathrm{bA}$ & $15,03 \mathrm{~A}$ \\
\hline \multirow{2}{*}{$\begin{array}{l}\text { Carne de } \\
\text { peito }(\%)\end{array}$} & I & $15,32 \mathrm{aA}$ & $13,08 \mathrm{bB}$ & $13,52 \mathrm{bA}$ & $14,09 \mathrm{abA}$ & $14,00 \mathrm{~A}$ \\
\hline & SI & $15,32 \mathrm{aA}$ & $14,01 \mathrm{bA}$ & $13,50 \mathrm{bA}$ & $13,68 \mathrm{bA}$ & $14,13 \mathrm{~A}$ \\
\hline
\end{tabular}

$\mathrm{a}, \mathrm{b}=$ letras minúsculas comparam médias na mesma linha para cada característica, dentro de cada sistema

$\mathrm{A}, \mathrm{B}=$ letras maiúsculas comparam médias na mesma coluna para cada característica, entre cada sistema 


\subsubsection{Efeito do sexo}

Os resultados das médias dos sexos em relação ao rendimento das partes principais da carcaça estão apresentados na Tabela 11. Não foram encontradas diferenças significativas $(\mathrm{P}>0,05)$ para as variáveis carcaça eviscerada e dorso.

Com relação ao rendimento de pernas, carne de perna $(\mathrm{P}<0,01)$ e asa $(\mathrm{P}<0,05)$, os machos apresentaram maiores percentagens que as fêmeas, com valores de 4,74\%, 7,50\% e 1,64\%, respectivamente. Entretanto, as fêmeas foram superiores $(\mathrm{P}<0,01)$ em percentagem de peito e carne de peito, com valores de $8,52 \%$ e $10,12 \%$, respectivamente.

As maiores percentagens de pernas apresentadas pelos machos, encontradas neste estudo, estão de acordo com trabalhos feitos com frango industrial realizados por Pezzato et al (1981), Murakami et al. (1983), Mendes (1990), Mendes et al.(1994), Politi et al. (1994), Souza et al. (1994), Lisboa (1995).

Rendimento de carne de pernas maior para machos, verificados neste estudo, não estão de acordo com resultados observados por Mendes (1990) e Mendes et al. (1993a) que não observaram diferenças entre sexos para rendimento de carne de pernas em frangos de linhagem industrial.

Os resultados encontrados neste estudo para maior percentagem de asa verificada para machos, discordam em parte dos observados por Mendes et al. (1993 a) e Politi et al. (1994) que não encontraram diferenças entre sexo para percentagem de asa de frangos industriais e, discordam quanto ao fato das diferenças de percentagem de asa terem sido observadas nas fêmeas por Garcia et al. (1991), Mendes (1990), Mendes et al. (1993 b).

Com relação à maior percentagem de peito verificada nas fêmeas deste estudo, resultados semelhantes foram reportados por Garcia et al. (1991), Mendes (1990), Mendes et al. (1993 b), Mendes et al. (1994) e Lisboa et al (1995) em trabalhos realizados com linhagens industrias de frangos de corte. Entretanto, Silveira \& Costa (1990) observaram que os machos apresentaram maior percentagem de peito em relação as fêmeas. 
Rendimento de carne de peito maior para fêmeas, verificados neste estudo, não estão de acordo com e Souza et al. (1994) que não observaram diferenças entre sexos para rendimento de carne de peito.

Tabela 11. Comparação entre médias das linhagens Label Rouge (LR), Caipirinha (CP), 7P e Paraíso Pedrês (PP), para as variáveis de rendimento das partes principais da carcaça, nos diferentes sexos.

\begin{tabular}{|c|c|c|c|c|c|c|}
\hline \multirow{2}{*}{ Característica } & \multirow{2}{*}{ Sexo } & \multicolumn{4}{|c|}{ LINHAGEM } & \multirow[b]{2}{*}{ Média } \\
\hline & & LR & $\mathrm{CP}$ & $7 \mathrm{P}$ & PP & \\
\hline \multirow{4}{*}{$\begin{array}{l}\text { Carcaça } \\
\text { eviscerada }(\%) \\
\text { Pernas }(\%)\end{array}$} & Macho & $68,30 \mathrm{aA}$ & $67,64 \mathrm{aA}$ & $67,39 \mathrm{aA}$ & $66,90 \mathrm{aA}$ & $67,56 \mathrm{~A}$ \\
\hline & Fêmea & $67,91 \mathrm{aA}$ & $66,95 \mathrm{aA}$ & $67,85 \mathrm{aA}$ & $65,75 \mathrm{aA}$ & $67,12 \mathrm{~A}$ \\
\hline & Macho & $23,30 \mathrm{aA}$ & $23,73 \mathrm{aA}$ & $23,92 \mathrm{aA}$ & $23,54 \mathrm{aA}$ & $23,62 \mathrm{~A}$ \\
\hline & Fêmea & $22,99 \mathrm{aA}$ & $22,14 \mathrm{aA}$ & $22,90 \mathrm{aA}$ & $21,97 \mathrm{aA}$ & $22,50 \mathrm{~B}$ \\
\hline \multirow[t]{2}{*}{ Asa (\%) } & Macho & $8,97 \mathrm{aA}$ & $8,74 \mathrm{aA}$ & $8,52 \mathrm{aA}$ & $8,46 \mathrm{bA}$ & $8,67 \mathrm{~A}$ \\
\hline & Fêmea & 8,79 aA & $8,26 \mathrm{aB}$ & $8,43 \mathrm{aA}$ & $8,64 \mathrm{aA}$ & $8,53 \mathrm{~B}$ \\
\hline \multirow[t]{2}{*}{ Peito (\%) } & Macho & $20,25 \mathrm{aA}$ & $19,39 \mathrm{aA}$ & $19,52 \mathrm{aA}$ & $20,08 \mathrm{aA}$ & $19,21 \mathrm{~B}$ \\
\hline & Fêmea & $20,96 \mathrm{aA}$ & $20,16 \mathrm{aA}$ & $20,94 \mathrm{aA}$ & $21,95 \mathrm{aA}$ & $21,00 \mathrm{~A}$ \\
\hline \multirow[t]{2}{*}{ Dorso (\%) } & Macho & $15,72 \mathrm{aA}$ & $15,48 \mathrm{aA}$ & $15,63 \mathrm{aA}$ & $16,26 \mathrm{aA}$ & $15,77 \mathrm{~A}$ \\
\hline & Fêmea & $14,97 \mathrm{bA}$ & $16,04 \mathrm{aA}$ & $15,40 \mathrm{abA}$ & $16,25 \mathrm{aA}$ & $15,67 \mathrm{~A}$ \\
\hline \multirow{2}{*}{$\begin{array}{l}\text { Carne de } \\
\text { Perna }(\%)\end{array}$} & Macho & $15,57 \mathrm{abA}$ & $15,69 \mathrm{aA}$ & $15,41 \mathrm{abA}$ & $14,81 \mathrm{bA}$ & $15,73 \mathrm{~A}$ \\
\hline & Fêmea & $15,06 \mathrm{aA}$ & $14,55 \mathrm{abB}$ & $14,62 \mathrm{abA}$ & $13,96 \mathrm{bB}$ & $14,55 \mathrm{~B}$ \\
\hline \multirow{2}{*}{$\begin{array}{l}\text { Carne de } \\
\text { peito }(\%)\end{array}$} & Macho & $14,59 \mathrm{aA}$ & $13,53 \mathrm{abA}$ & $13,01 \mathrm{bA}$ & $13,28 \mathrm{abA}$ & $13,06 \mathrm{~B}$ \\
\hline & Fêmea & $16,05 \mathrm{aA}$ & $13,57 \mathrm{bA}$ & $14,03 \mathrm{bA}$ & $14,49 \mathrm{bA}$ & $14,53 \mathrm{~A}$ \\
\hline \multicolumn{7}{|c|}{$\begin{array}{l}\text { a , b = letras minúsculas comparam médias na mesma linha para cada característica, } \\
\text { dentro de cada sexo }\end{array}$} \\
\hline
\end{tabular}

\subsubsection{Linhagem e sistema de criação}

Observou-se efeito significativo da interação linhagem $x$ sistema de criação para percentagem de carne de peito $(\mathrm{P}<0,05)$. A ordem de manifestação das linhagens foi alterada entre os sistemas, permanecendo dentro do sistema intensivo de 
criação as linhagens LR, PP, 7P e CP, enquanto que no semi-intensivo LR, CP, PP e 7P, respectivamente (Figura 3).

As linhagens de crescimento lento (LR e CP) apresentaram maior deposição de carne de peito no sistema semi-intensivo, do que as linhagens de crescimento rápido (PP e 7P).

Vale ressaltar que as linhagens que apresentaram menor GPMD (LR e CP) e maior idade 2300 (LR e CP) no sistema semi-intensivo, foram as que apresentaram maior percentagem de carne de peito também no sistema semi-intensivo.

Esses resultados sugerem que o maior tempo para idade 2300 gasto pelas linhagens de crescimento lento e o menor GPMD favoreceram o maior ganho de carne de peito no sistema semi-intensivo, enquanto que as linhagens de crescimento rápido, apesar de terem apresentado maior velocidade de ganho de peso, não foram eficientes para converter esse ganho em carne de peito.

A linhagem $\mathrm{CP}$ foi a única que apresentou diferença significativa $(\mathrm{P}<0,05)$ em percentagem de carne de peito entre sistemas, sendo que o sistema semiintensivo apresentou 0,93 \% maior rendimento de carne de peito que o sistema intensivo (Tabela 10). O menor rendimento de carne de peito no sistema intensivo de criação da linhagem CP pode ter sido em decorrência do menor tempo que a linhagem levou apara atingir a idade 2300 . 


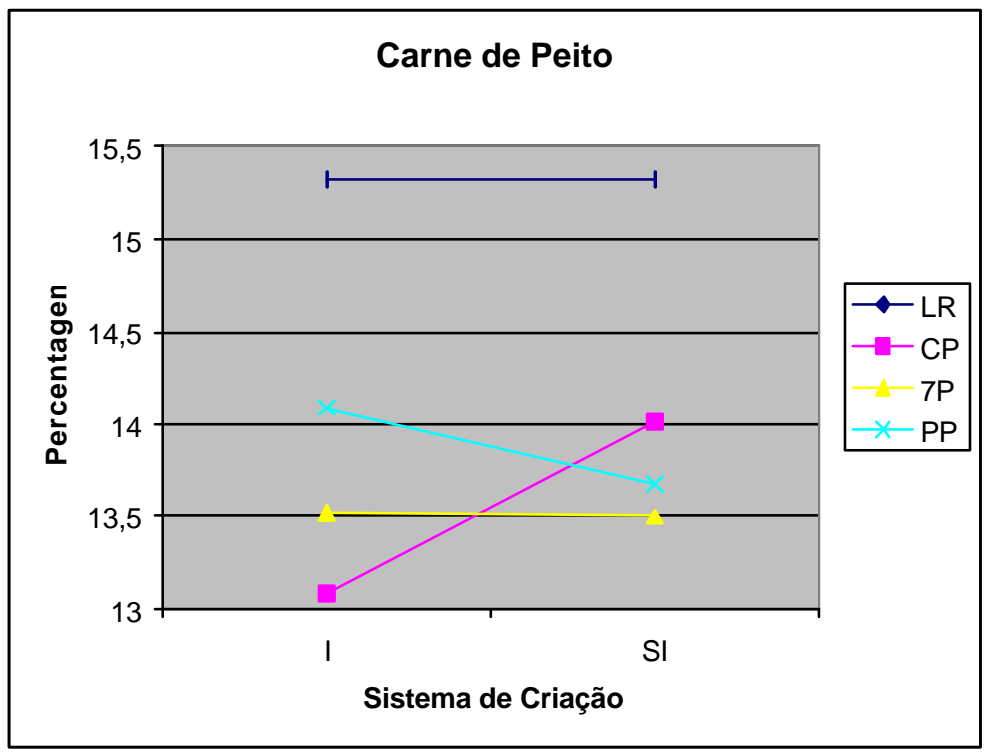

Figura 3 - Interação linhagem x sistema de criação para a variável rendimento de carne de peito

As demais variáveis de rendimento de partes principais de carcaça não apresentaram efeito significativo $(\mathrm{P}>0,05)$ da interação linhagem $\mathrm{x}$ sistema de criação.

Apesar de não ter sido verificada interação entre linhagem x sistema de criação para as demais variáveis de rendimento de partes principais da carcaça, considerando-se as linhagens dentro de cada um dos sistemas de criação, observou-se diferença para percentagem de dorso e carne de perna apenas dentro do sistema semiintensivo de criação.

Comparando as linhagens dentro do sistema semi-intensivo de criação em relação a variável percentagem de dorso, as linhagens $\mathrm{PP}, 7 \mathrm{P}$ e $\mathrm{CP}$ não apresentaram diferença significativa $(\mathrm{P}>0,05)$, assim como as linhagens $7 \mathrm{P}, \mathrm{CP}$ e $\mathrm{LR}$, no entanto, a linhagem CP apresentou 5,97 \% a menos de rendimento de dorso em relação a linhagem PP (Tabela 10).

Com relação à diferença entre as linhagens dentro do sistema semiintensivo de criação para a variável percentagem de perna, $L R, C P$ e $7 \mathrm{P}$ não apresentaram diferença significativa $(\mathrm{P}>0,05)$ entre si, porém, a linhagem PP apresentou 
8,$1 ; 7,8$ e $6,0 \%$ a menos rendimento e carne de perna $(\mathrm{P}<0,05)$, respectivamente, que as linhagens LR, CP e 7P (Tabela 10).

\subsubsection{Linhagem e sexo}

Observou-se efeito significativo da interação linhagem $x$ sexo para percentagem de asa $(\mathrm{P}<0,05)$. A ordem de manifestação das linhagens foi alterada entre os sexos, permanecendo dentro de macho as linhagens LR, CP, 7P e PP, enquanto que no semi-intensivo LR, PP, 7P e CP, respectivamente (Figura 4).

A linhagem $\mathrm{CP}$ foi a única que apresentou diferença significativa $(\mathrm{P}<0,05)$ em percentagem asa entre sexos, sendo que os machos apresentaram 5,5\% maior rendimento de asa do as que fêmeas (Tabela 11).

Em relação as demais linhagens, não foram encontradas diferenças $(\mathrm{P}>0,05)$ entre os sexos para a mesma característica. No entanto, nas linhagens LR, CP e 7P os machos apresentaram uma maior tendência que as fêmeas para rendimento de asa, sendo que para a linhagem PP foi observado o contrário.

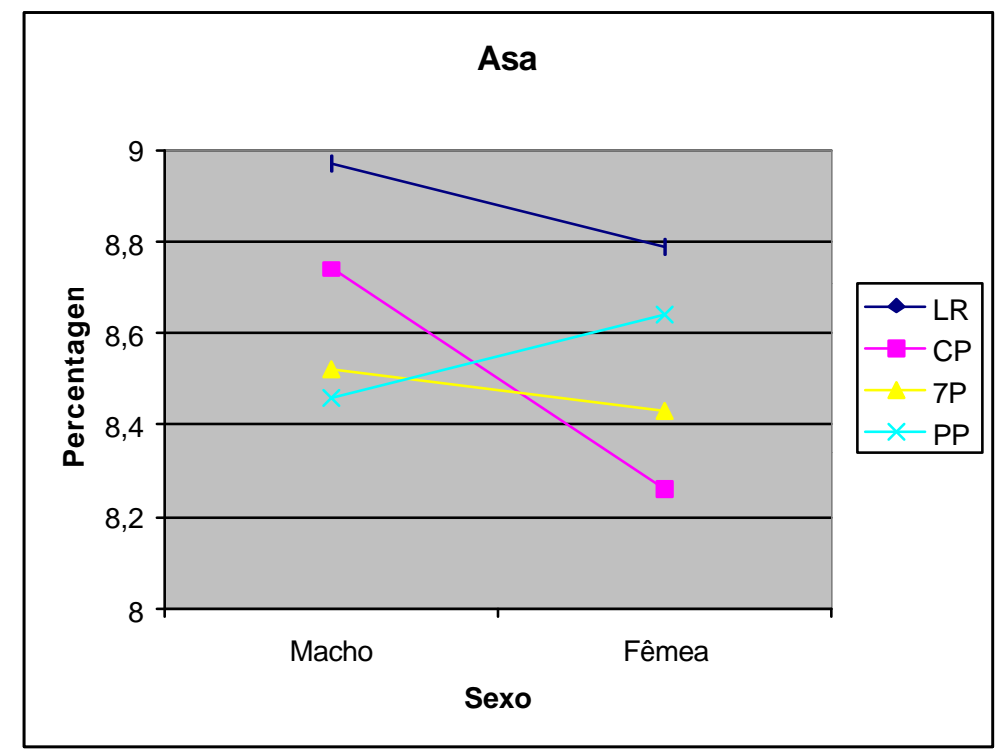

Figura 4 - Interação linhagem x sexo para a variável percentagem de asa. 
Apesar de não ter sido encontrado efeito significativo $(\mathrm{P}>0,05)$ da interação linhagem x sexo para as demais variáveis de rendimento de partes principais da carcaça estudadas, considerando-se as linhagens dentro de cada um dos sexos, observou-se diferença para percentagem de carne de perna e carne de peito dentro dos dois sexos. A variável percentagem de dorso apresentou diferenças entre as linhagens apenas dentro de fêmea.

Em relação as linhagens dentro do sexo macho, $\mathrm{CP}$, LR e $7 \mathrm{P}$ não apresentaram diferenças $(\mathrm{P}>0,05)$ entre si, assim como os machos das linhagens $7 \mathrm{P}$, LR e PP para a variável percentagem de pernas, entretanto os machos da linhagem PP apresentaram 5,6 \% a menos de carne de pernas que a linhagem CP. Com relação a mesma variável entre as linhagens dentro do sexo fêmea, LR, 7P e CP, assim como as linhagens 7P, CP e PP não diferiram significativamente $(\mathrm{P}>0,05)$, porém, a linhagem $\mathrm{PP}$ apresentou 7,3\% a menos de carne de pernas que a linhagem LR (Tabela 11).

Os machos das linhagens LR, CP e PP, assim como os machos das linhagens $\mathrm{CP}$, PP e 7P não apresentaram diferenças significativas $(\mathrm{P}>0,05)$ para a variável carne de peito, entretanto, a linhagem $7 \mathrm{P}$ apresentou $10,8 \%$ a menos de carne de peito que a linhagem LR (Tabela 11). Com relação as fêmeas, as linhagens PP, 7P e $\mathrm{CP}$ não diferiram significativamente ( $\mathrm{P}>0,05)$, porém , a linhagem $\mathrm{CP}$ apresentou 9,7; 12,6 e $15,5 \%$, respectivamente, a mais de carne de peito do que as linhagens PP, 7P e CP (Tabela 11).

Com relação a percentagem de dorso dentro do sexo fêmea, as linhagens $\mathrm{CP}$, PP e 7P, assim como as linhagens 7P e LR não diferiram significativamente (P>0,05), entretanto, a linhagem LR apresentou 7,9 e $6.7 \%$ a menos de dorso que as linhagens PP e CP, respectivamente (Tabela 11). 


\subsubsection{Rendimento das partes secundárias da carcaça}

\subsubsection{Efeito de linhagem}

Os resultados das médias das linhagens em relação ao rendimento das partes secundárias da carcaça, estão apresentados na Tabela 12.

Para as varáveis pele de perna, vísceras, pés e cabeça + pescoço, não foram encontradas diferenças significativas $(\mathrm{P}>0,05)$ entre linhagens.

Com relação à percentagem de osso de perna, osso de peito e pele de peito, a linhagem PP apresentou maior rendimento em relação as demais linhagens. Considerando-se apenas o osso de perna, a linhagem PP não diferiu significativamente $(\mathrm{P}>0,05)$ da linhagem $7 \mathrm{P}$ e nem as linhagens 7P, CP e LR diferiram entre si. Porém, PP diferiu significativamente $(\mathrm{P}<0,01)$, das linhagens LR e CP, com valores $16,44 \%$ e $16,10 \%$ maiores, respectivamente (Tabela 12 ).

Politi et al. (1994), ao avaliarem o efeito da linhagem e sexo sobre o desempenho e rendimento de carcaça de frangos de corte industrial, encontraram diferenças significativas $(\mathrm{P}<0,05)$ entre linhagens para osso de coxa, entretanto neste estudo fora encontradas diferenças entre linhagens para percentagem de osso de perna (coxa e sobrecoxa). Mendes (1990) e Mendes et al. (1993a) não encontraram diferenças entre linhagens para percentagem de osso de pernas.

Analisando-se apenas o osso de peito, não diferiram significativamente $(\mathrm{P}>0,05)$ as linhagens $7 \mathrm{P}$ e $\mathrm{CP}$ e nem as linhagens CP e LR, no entanto, a linhagem PP diferiu significativamente $(\mathrm{P}<0,01)$ em relação as linhagens $7 \mathrm{P}, \mathrm{LR}$ e $\mathrm{CP}$, apresentando valores de rendimento 6,$56 ; 13,14 \%$ e 10,22\% maiores, respectivamente (Tabela 12).

Mendes (1990), Mendes et al. (1993a) e Politi et al. (1994) não encontraram diferença significativa de linhagem para percentagem de osso de peito de linhagens industriais de frango de corte, discordando portanto dos resultados encontrados neste estudo.

Na comparação do rendimento de pele de peito, a linhagem PP não diferiu significativamente $(\mathrm{P}>0,05)$ de $7 \mathrm{P}$, e também não diferiram as linhagens $7 \mathrm{P}$ e $\mathrm{CP}$ e nem 
CP e LR. As diferenças significativas $(\mathrm{P}<0,01)$ da linhagem PP em relação as linhagens LR e CP foram 37,46 e 24,74\%, respectivamente. A linhagem 7P diferiu significativamente $(\mathrm{P}<0,01)$ em relação as linhagens $\mathrm{LR}$, apresentando valor de rendimento 27,78\% maior (Tabela 12).

$\mathrm{O}$ efeito significativo de linhagem sobre o rendimento de pele de peito, encontrado neste estudo, foi semelhantes ao encontrado por Politi et al. (1994) em linhagens industriais de frango de corte; entretanto Mendes et al. (1993a) não verificaram efeito de linhagem sobre percentagem de pele de peito em frango de corte industrial.

A linhagem 7P apresentou as maiores diferenças em relação ao rendimento de gordura abdominal, porém não diferiram significativamente $(\mathrm{P}>0,05)$ as linhagens 7P e CP, CP e PP e nem LR e PP. O maior rendimento de gordura abdominal da linhagem 7P em relação as linhagens PP e LR foi de 16,71\% e 26,46\%, respectivamente, e a diferença significativa $(\mathrm{P}<0,01)$ do rendimento de gordura abdominal da linhagem CP em relação à LR, foi de $18,01 \%$. Para as variáveis pele de perna, vísceras, pés e cabeça + pescoço não foram encontradas diferenças significativas ( $\mathrm{P}>0,05)$, entre as linhagens.(Tabela 12).

Figueiredo (2001) apresenta diferenças entre linhagens comerciais de frango tipo caipira para gordura abdominal. Estes resultados foram semelhantes ao encontrado neste estudo.

Com relação ao efeito de linhagem para gordura abdominal verificado neste estudo, Politi et al. (1994), Lisboa (1995), Abreu et al. (1996a) e Abreu et al. (1996b) encontraram resultados semelhantes com linhagens industriais de frango de corte; entretanto Mendes et al. (1994) não encontraram efeito de linhagem para rendimento de gordura abdominal. 
Tabela 12. Comparação entre médias das linhagens Label Rouge (LR), Caipirinha (CP), 7P e Paraíso Pedrês (PP), para as variáveis rendimento das partes secundárias da carcaça.

\begin{tabular}{|c|c|c|c|c|}
\hline \multirow{2}{*}{ Características } & \multicolumn{4}{|c|}{ LINHAGEM } \\
\hline & LR & $\mathrm{CP}$ & $7 \mathrm{P}$ & $\mathrm{PP}$ \\
\hline Osso perna $(\%)^{1}$ & $4,93 \mathrm{~b}$ & $4,95 \mathrm{~b}$ & $5,61 \mathrm{ab}$ & $5,90 \mathrm{a}$ \\
\hline Osso peito $(\%)^{1}$ & $3,57 \mathrm{c}$ & $3,69 \mathrm{bc}$ & $3,84 \mathrm{~b}$ & $4,11 \mathrm{a}$ \\
\hline Pele perna $(\%)$ & $2,31 \mathrm{a}$ & $2,98 \mathrm{a}$ & $2,68 \mathrm{a}$ & $2,94 \mathrm{a}$ \\
\hline Pele peito $(\%)$ & $1,82 \mathrm{c}$ & $2,19 \mathrm{cb}$ & $2,52 \mathrm{ab}$ & $2,91 \mathrm{a}$ \\
\hline Gordura abdominal (\%) ${ }^{1}$ & $2,64 \mathrm{c}$ & $3,22 \mathrm{ab}$ & $3,59 \mathrm{a}$ & $2,99 \mathrm{bc}$ \\
\hline Vísceras $(\%)$ & $9,77 \mathrm{a}$ & $10,05 \mathrm{a}$ & $10,45 \mathrm{a}$ & $9,76 \mathrm{a}$ \\
\hline Pés $(\%)$ & $3,67 \mathrm{a}$ & $3,60 \mathrm{a}$ & $3,83 \mathrm{a}$ & $3,86 \mathrm{a}$ \\
\hline Cabeça $+\operatorname{pescoço~}(\%)$ & $6,80 \mathrm{a}$ & $7,35 \mathrm{a}$ & $6,64 \mathrm{a}$ & $6,54 \mathrm{a}$ \\
\hline
\end{tabular}

$\mathrm{a}, \mathrm{b}=$ letras minúsculas comparam médias na mesma linha para cada característica, pelo teste de Tukey $\left({ }^{1} \mathrm{p}<0,01\right)$

\subsubsection{Efeito do sistema de criação}

Os resultados das médias dos sistemas de criação, em relação ao rendimento das partes secundárias da carcaça, estão apresentados na Tabela 13.

Não foram encontradas diferenças significativas $(\mathrm{P}<0,05)$ para nenhuma das variáveis estudas, mostrando portanto, que as aves criadas tanto no sistema intensivo quanto no sistema semi-intensivo, obtiveram os mesmos rendimentos. 
Tabela 13. Comparação entre médias das linhagens Label Rouge (LR), Caipirinha (CP), 7P e Paraíso Pedrês (PP), para as variáveis de rendimento das partes secundárias da carcaça, nos sistemas intensivo (I) e semi intensivo (SI) de criação de criação.

\begin{tabular}{|c|c|c|c|c|c|c|}
\hline \multirow{2}{*}{ Característica } & \multirow{2}{*}{ Sistema } & \multicolumn{4}{|c|}{ LINHAGEM } & \multirow{2}{*}{ Média } \\
\hline & & LR & $\mathrm{CP}$ & $7 \mathrm{P}$ & PP & \\
\hline \multirow{2}{*}{ Osso perna $(\%)$} & I & $4,78 \mathrm{cA}$ & $4,97 \mathrm{bcA}$ & $5,60 \mathrm{abA}$ & $5,75 \mathrm{aA}$ & $5,27 \mathrm{~A}$ \\
\hline & SI & 5,13 bcA & $4,89 \mathrm{cA}$ & $5,63 \mathrm{abA}$ & $6,06 \mathrm{aA}$ & $5,43 \mathrm{~A}$ \\
\hline \multirow{2}{*}{ Osso peito $(\%)$} & I & $3,75 \mathrm{aA}$ & $3,84 \mathrm{aA}$ & $3,89 \mathrm{aA}$ & $4,18 \mathrm{aA}$ & $3,91 \mathrm{~A}$ \\
\hline & SI & $3,39 \mathrm{bA}$ & $3,55 \mathrm{bA}$ & $3,79 \mathrm{abA}$ & $4,05 \mathrm{aA}$ & $3,69 \mathrm{~A}$ \\
\hline \multirow{2}{*}{ Pele perna $(\%)$} & I & 2,32 aA & $2,80 \mathrm{aA}$ & $2,75 \mathrm{aA}$ & $3,07 \mathrm{aA}$ & $2,74 \mathrm{~A}$ \\
\hline & SI & $2,30 \mathrm{aA}$ & 3,16 aA & $2,60 \mathrm{aA}$ & $2,81 \mathrm{aA}$ & $2,72 \mathrm{~A}$ \\
\hline \multirow{2}{*}{ Pele peito $(\%)$} & I & $1,91 \mathrm{bA}$ & $2,32 \mathrm{aA}$ & $2,56 \mathrm{aA}$ & $2,80 \mathrm{aA}$ & $2,40 \mathrm{~A}$ \\
\hline & SI & $1,73 \mathrm{cA}$ & $2,06 \mathrm{bcA}$ & $2,49 \mathrm{abA}$ & $3,02 \mathrm{aA}$ & $2,32 \mathrm{~A}$ \\
\hline \multirow{2}{*}{$\begin{array}{l}\text { Gordura } \\
\text { abdominal (\%) }\end{array}$} & I & $2,60 \mathrm{bA}$ & $3,39 \mathrm{abA}$ & $3,69 \mathrm{aA}$ & $2,96 \mathrm{abA}$ & $3,16 \mathrm{~A}$ \\
\hline & SI & $2,69 \mathrm{aA}$ & $3,05 \mathrm{aA}$ & $3,50 \mathrm{aA}$ & $3,01 \mathrm{aA}$ & $3,06 \mathrm{~A}$ \\
\hline \multirow{2}{*}{ Vísceras (\%) } & I & $9,60 \mathrm{aA}$ & $10,36 \mathrm{aA}$ & $10,26 \mathrm{aA}$ & $9,6 \mathrm{aA}$ & $9,95 \mathrm{~A}$ \\
\hline & SI & $9,94 \mathrm{aA}$ & $9,75 \mathrm{aA}$ & $10,64 \mathrm{aA}$ & $9,91 \mathrm{aA}$ & $10,06 \mathrm{~A}$ \\
\hline \multirow{2}{*}{ Pés (\%) } & I & $3,64 \mathrm{aA}$ & $3,56 \mathrm{aA}$ & $3,72 \mathrm{aA}$ & $3,84 \mathrm{aA}$ & $3,80 \mathrm{~A}$ \\
\hline & SI & $3,70 \mathrm{aA}$ & $3,65 \mathrm{aA}$ & $3,94 \mathrm{aA}$ & $3,89 \mathrm{abA}$ & $3,69 \mathrm{~A}$ \\
\hline \multirow{2}{*}{$\begin{array}{l}\text { Cabeça }+ \text { pescoço } \\
(\%)\end{array}$} & I & $6,93 \mathrm{aA}$ & $7,06 \mathrm{aA}$ & $6,67 \mathrm{aA}$ & $6,54 \mathrm{aA}$ & $6,86 \mathrm{~A}$ \\
\hline & SI & $6,68 \mathrm{aA}$ & $7,63 \mathrm{aA}$ & $6,61 \mathrm{aA}$ & $6,54 \mathrm{aA}$ & $6,80 \mathrm{~A}$ \\
\hline
\end{tabular}

$\mathrm{a}, \mathrm{b}=$ letras minúsculas comparam médias na mesma linha para cada característica, dentro de cada sistema

A, B = letras maiúsculas comparam médias na mesma coluna para cada característica, entre os sistemas 


\subsubsection{Efeito do sexo}

Os resultados das médias dos sexos em relação ao rendimento das partes secundárias da carcaça, estão apresentados na Tabela 14.

Com relação ao rendimento de osso de perna e pés os machos apresentaram maiores percentagens que as fêmeas $(\mathrm{P}<0,01)$, com valores de 9,61\% e 19,08\%, respectivamente. Entretanto, as fêmeas foram superiores $(\mathrm{P}<0,01)$ em percentagem de pele de peito, gordura abdominal e vísceras, com valores de 11,55\%, $24,79 \%, 3,44 \%$, respectivamente.

Rendimento maior de osso de perna para machos encontrado neste estudo foi semelhante aos trabalhos de Mendes (1990), Politi et al. (1994) e Mendes et al. (1993a) com linhagens de frango industrial quando comparam o rendimento em relação ao peso vivo do frango; entretanto foi diferente ao trabalho de Mendes et al. (1993a) que não encontraram diferença entre sexos para osso de perna quando compararam o rendimento em relação ao peso de carcaça eviscerada de frangos de corte de linhagem industrial.

Com relação ao maior rendimento de pés para machos encontrado neste estudo, os trabalhos realizados por Pezzato et al. (1981), Garcia \& Silva (1984), Mendes (1990), Garcia (1991), Garcia et al. (1993) e Mendes et al. (1994) em linhagens industriais de frango de corte, foram semelhantes. Entretanto, Souza et al. (1994) e Mendes et al. (1993a) não encontraram diferenças significativas $(\mathrm{P}>0,05)$ entre sexos para rendimento de pés.

O maior rendimento de pele de peito encontrado nas fêmeas neste estudo foi semelhante aos resultados encontrados por Mendes (1990) e Mendes et al. (1993a) quando compararam a percentagem de pele de peito de linhagem industrial de frango de corte, tanto em relação ao peso vivo como ao peso de carcaça eviscerada.

Em relação ao sexo, parece evidente que as fêmeas apresentam maior tendência a depositar gordura abdominal que os machos (Mendes, 1990; Garcia et al., 1993; Avila et al., 1993; Mendes et al., 1994; Politi et al., 1994; Lisboa, 1995; Mendes et al., 1995; Schmidt \& Custódio, 1998 e Leu, 2000), portanto, a maior percentagem de 
gordura abdominal deste estudo está dentro do esperado em relação às linhagens de frango de corte industrial.

Não foram encontradas diferenças significativas $(\mathrm{P}>0,05)$ entre os sexos para as variáveis osso de peito, pele de perna e cabeça + pescoço.

Tabela 14. Comparação entre médias das linhagens Label Rouge (LR), Caipirinha (CP), 7P e Paraíso Pedrês (PP), para as variáveis rendimento das partes secundárias da carcaça, nos diferentes sexos.

\begin{tabular}{|c|c|c|c|c|c|c|}
\hline \multirow{2}{*}{ Característica } & \multirow{2}{*}{ Sexo } & \multicolumn{4}{|c|}{ LINHAGEM } & \multirow{2}{*}{ Média } \\
\hline & & LR & $\mathrm{CP}$ & $7 \mathrm{P}$ & PP & \\
\hline \multirow[t]{2}{*}{ Osso perna (\%) } & Macho & $5,27 \mathrm{bA}$ & $5,35 \mathrm{abA}$ & $5,88 \mathrm{abA}$ & $5,98 \mathrm{aA}$ & $5,62 \mathrm{~A}$ \\
\hline & Fêmea & $4,63 \mathrm{bA}$ & $4,51 \mathrm{bB}$ & $5,35 \mathrm{aA}$ & $5,83 \mathrm{aA}$ & $5,08 \mathrm{~B}$ \\
\hline \multirow[t]{2}{*}{ Osso peito $(\%)$} & Macho & $3,66 \mathrm{aA}$ & $3,83 \mathrm{aA}$ & $3,80 \mathrm{aA}$ & 3,96 aA & $3,81 \mathrm{~A}$ \\
\hline & Fêmea & $3,48 \mathrm{bA}$ & $3,56 \mathrm{bA}$ & $3,88 \mathrm{abA}$ & $4,27 \mathrm{aA}$ & $3,80 \mathrm{~A}$ \\
\hline \multirow[t]{2}{*}{ Pele perna $(\%)$} & Macho & $2,17 \mathrm{bA}$ & $3,07 \mathrm{aA}$ & $2,49 \mathrm{abA}$ & $2,80 \mathrm{abA}$ & $2,63 \mathrm{~A}$ \\
\hline & Fêmea & $2,45 \mathrm{aA}$ & $2,90 \mathrm{aA}$ & $2,87 \mathrm{aA}$ & $3,07 \mathrm{aA}$ & $2,82 \mathrm{~A}$ \\
\hline \multirow[t]{2}{*}{ Pele peito $(\%)$} & Macho & $1,75 \mathrm{cA}$ & $2,03 \mathrm{bcA}$ & $2,35 \mathrm{abA}$ & $2,70 \mathrm{aA}$ & $2,22 \mathrm{~B}$ \\
\hline & Fêmea & $1,88 \mathrm{cA}$ & $2,35 \mathrm{bA}$ & $2,70 \mathrm{abA}$ & $3,12 \mathrm{aA}$ & $2,51 \mathrm{~A}$ \\
\hline \multirow{2}{*}{$\begin{array}{l}\text { Gordura } \\
\text { abdominal (\%) }\end{array}$} & Macho & $2,19 \mathrm{bB}$ & $2,49 \mathrm{abB}$ & $3,26 \mathrm{aA}$ & $2,74 \mathrm{abA}$ & $2,67 \mathrm{~B}$ \\
\hline & Fêmea & $3,09 \mathrm{aA}$ & $3,95 \mathrm{aA}$ & $3,93 \mathrm{aA}$ & $3,24 \mathrm{aA}$ & $3,55 \mathrm{~A}$ \\
\hline Vísceras (\%) & Macho & $9,70 \mathrm{aA}$ & $9,89 \mathrm{aA}$ & $10,40 \mathrm{aA}$ & $9,34 \mathrm{aA}$ & $9,83 \mathrm{~B}$ \\
\hline \multirow{3}{*}{ Pés (\%) } & Fêmea & $9,83 \mathrm{aA}$ & $10,21 \mathrm{aA}$ & $10,50 \mathrm{aA}$ & $10,18 \mathrm{aA}$ & $10,18 \mathrm{~A}$ \\
\hline & Macho & $4,05 \mathrm{aA}$ & $4,01 \mathrm{aA}$ & $4,37 \mathrm{aA}$ & $4,14 \mathrm{aA}$ & $4,14 \mathrm{~A}$ \\
\hline & Fêmea & $3,30 \mathrm{abB}$ & $3,20 \mathrm{bB}$ & $3,29 \mathrm{abB}$ & $3,59 \mathrm{aB}$ & $3,35 \mathrm{~B}$ \\
\hline \multirow{2}{*}{$\begin{array}{l}\text { Cabeça + pescoço } \\
(\%)\end{array}$} & Macho & $7,15 \mathrm{aA}$ & $7,73 \mathrm{aA}$ & $6,64 \mathrm{aA}$ & $6,71 \mathrm{aA}$ & $6,61 \mathrm{~A}$ \\
\hline & Fêmea & $6,46 \mathrm{aA}$ & $6,97 \mathrm{aA}$ & $6,64 \mathrm{aA}$ & $6,37 \mathrm{aA}$ & $7,06 \mathrm{~A}$ \\
\hline
\end{tabular}

A, B = letras maiúsculas comparam médias na mesma coluna para cada característica, entre cada sexo 


\subsubsection{Linhagem e sistema de criação}

Apesar de não ter sido encontrado efeito significativo $(\mathrm{P}>0,05)$ da interação linhagem x sistema de criação para nenhuma das variáveis de rendimento de partes secundárias da carcaça estudadas, considerando-se as linhagens dentro de cada um dos sistemas de criação, observou-se diferença para percentagem de osso de perna e pele de peito dentro dos sistemas intensivo e semi-intensivo de criação. A variável gordura abdominal apresentou diferenças entre as linhagens apenas dentro do sistema intensivo de criação e a variável osso de peito apresentou diferenças entre as linhagens apenas dentro do sistema semi-intensivo de criação.

Comparando as linhagens dentro do sistema intensivo de criação em relação a variável osso de perna, não diferiram significativamente $(\mathrm{P}>0,05)$ as linhagens PP e 7P, 7P e CP e nem CP e LR. A linhagem PP apresentou 13,56 e 16,90\% maior rendimento de osso de perna que CP e LR, respectivamente, e 7P apresentou 14,64\% maior que LR (Tabela 13). Com relação a mesma variável entre as linhagens dentro do sistema semi-intensivo, $P P$ e 7P, 7P e LR, CP e LR não diferiram significativamente ( $P>0,05)$, entretanto, a linhagem PP apresentou 15,35 e 19,31\% maior rendimento de osso de perna que LR e CP, respectivamente, e 7P apresentou 8,88 \% maior que LR (Tabela 12).

Quando as linhagens foram comparadas dentro do sistema intensivo de criação para a variável pele de peito, não diferiram significativamente $(\mathrm{P}>0,05) \mathrm{PP}, 7 \mathrm{P}$ e CP. A linhagem LR apresentou menor rendimento de pele de peito $(\mathrm{P}<0,05)$ em relação às linhagens $\mathrm{PP}, 7 \mathrm{P}$ e $\mathrm{CP}$ com valores 31,80; 25,39 e 17,76 \%, respectivamente. Comparando a mesma variável entre as linhagens dentro do sistema semi-intensivo de criação, PP e 7P, 7P e CP e CP e LR não diferiram significativamente ( $\mathrm{P}>0,05)$, porém , a linhagem PP apresentou 31,79 e 42,71\% maior rendimento de pele de peito que CP e LR, respectivamente, e 7P apresentou 30,52 \% maior que LR (Tabela 13).

Em relação à variável gordura abdominal, as linhagens $7 \mathrm{P}, \mathrm{CP}$ e $\mathrm{PP}$ não apresentaram diferença significativa $(\mathrm{P}>0,05)$, e nem $\mathrm{CP}$, PP e LR, entretanto a 
linhagem 7P apresentou o maior rendimento de gordura abdominal, diferindo $(\mathrm{P}<0,05)$ apenas em relação à linhagem CP com valor de 29,53 \% (Tabela 13).

Com relação à variável osso de peito, as linhagens $\mathrm{PP}$ e $7 \mathrm{P}$ não diferiram $(\mathrm{P}>0,05)$ e nem as linhagens 7P, CP e LR. A linhagem PP apresentou 12,35 e 16,30\% maior rendimento que as linhagens CP e LR, respectivamente (Tabela 13)

Não foram encontradas diferenças significativas $(\mathrm{P}>0,05)$ entre as linhagens para nenhum dos sistemas de criação para as variáveis pele de perna, vísceras, pés e cabeça + pescoço. 


\subsubsection{Linhagem e sexo}

Foi encontrado efeito significativo $(\mathrm{P}<0,05)$ da interação linhagem $\mathrm{x}$ sexo, para percentagem de pés. A ordem de manifestação das linhagens foi alterada entre os sexos, permanecendo dentro de macho as linhagens 7P, PP, LR e CP, enquanto que no semi-intensivo PP, LR, 7P e CP, respectivamente (Figura 5).

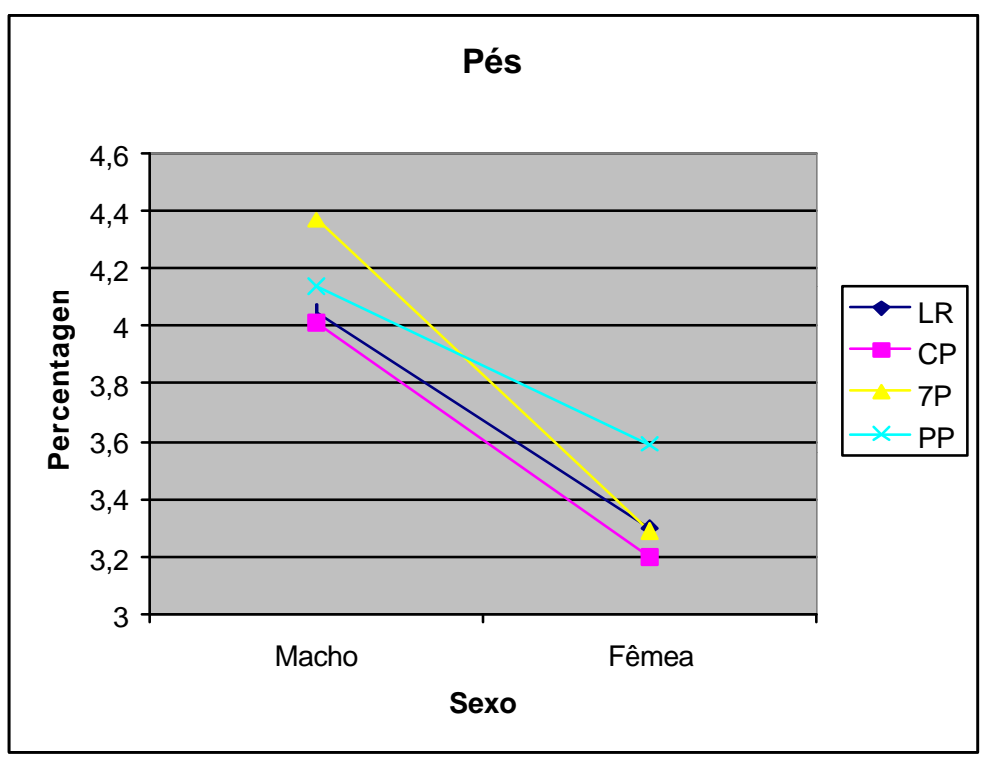

Figura 5 - Interação linhagem e sexo para variável percentagem de pés.

Em todas as linhagens foram verificadas diferenças significativas $(\mathrm{P}<0,05)$ para percentagem de pés entre sexo, onde os machos das linhagens $7 \mathrm{P}, \mathrm{CP}, \mathrm{LR}$ e PP apresentaram 24,71; 20,19; 18,54 e 13,28 \% maior rendimento que as fêmeas, respectivamente.

Apesar de não ter sido encontrado efeito significativo $(\mathrm{P}>0,05)$ da interação linhagem x sexo para as demais variáveis de rendimento de partes secundárias da carcaça estudadas, considerando-se as linhagens dentro de cada um dos sexos, observou-se diferença para percentagem de osso de perna e pele de peito dentro dos dois sexos. As variáveis pele de perna e gordura abdominal apresentaram diferenças entre as 
linhagens apenas dentro do sexo macho e a variável osso de peito apresentou diferenças entre as linhagens apenas dentro de fêmea.

Em relação às linhagens dentro do sexo macho a variável osso de perna, não diferiram significativamente $(\mathrm{P}>0,05)$ as linhagens $\mathrm{PP}, 7 \mathrm{P}$ e $\mathrm{CP}$ e nem $7 \mathrm{P}, \mathrm{CP}$ e $\mathrm{LR}$; entretanto, a linhagem PP apresentou o maior rendimento de osso de perna $(\mathrm{P}<0,05)$, diferindo 11,90 \% de LR (Tabela 14). Com relação a mesma variável entre as linhagens dentro do sexo fêmea, $P P$ e 7P, $C P$ e LR não diferiram significativamente $(P>0,05)$, entretanto, a linhagem PP apresentou 20,60 e 22,64 \% maior rendimento de osso de perna que LR e CP, respectivamente, e 7P apresentou 13,50 e 15,70\% maior que LR e $\mathrm{CP}$, respectivamente (Tabela 14$)$.

As linhagens PP e 7P, 7P e CP, CP e LR não diferiram significativamente $(\mathrm{P}>0,05)$ dentro do sexo macho em relação à variável pele de peito. A linhagem PP apresentou o maior rendimento de osso de perna $(\mathrm{P}<0,05)$, diferindo 24,81 e 35,19\% de CP e LR, respectivamente, e 7P apresentou 25,53.\%.maior rendimento que LR (Tabela 14). Com relação a mesma variável entre as linhagens dentro do sexo fêmea, PP e 7P, 7P e $\mathrm{CP}$ não diferiram significativamente $(\mathrm{P}>0,05)$, entretanto, a linhagem $\mathrm{PP}$ apresentou 24,68 e 39,74 \% maior rendimento de osso de perna que CP e LR, respectivamente, e 7P apresentou 12,96 e 30,37 \% maior que CP e LR, respectivamente, e CP apresentou $20,00 \%$ maior que LR (Tabela 14).

Em relação à percentagem de pele de perna, as linhagens $\mathrm{PP}, 7 \mathrm{P}$ e CP não diferiram significativamente $(\mathrm{P}>0,05)$, e nem as linhagens PP, 7P e LR. A linhagem CP apresentou 29,32.\% maior rendimento de pele de perna em relação à LR dentro do sexo macho (Tabela 14).

Com relação à variável gordura abdominal, as linhagens PP, 7P e CP não diferiram significativamente $(\mathrm{P}>0,05)$ dentro do sexo macho e nem CP e LR. A linhagem LR apresentou 20,07 e 32,82 \% menor rendimento de gordura abdominal que as linhagens PP e 7P, respectivamente (Tabela 14).

Considerando-se a variável osso de peito, as linhagens PP e 7P não diferiram significativamente $(\mathrm{P}>0,05)$ e nem as $7 \mathrm{P}, \mathrm{CP}$ e LR. A linhagem PP apresentou 
18,50 \% maior de rendimento de osso de peito dentro do sexo fêmea que a linhagem LR (Tabela 14).

As variáveis vísceras e cabeça + pescoço não apresentaram diferenças significativas entre as linhagens dentro dos diferentes sexos. 


\section{CONCLUSÕES}

- Existem respostas diferenciadas no desempenho e no rendimento de partes principais e secundárias da carcaça de linhagens de frangos de corte tipo caipira, criadas nos sistemas intensivo e semi-intensivo de criação.

- O sistema de criação influenciou a idade 2300, GPMD e a percentagem de dorso de frangos tipo caipira, sendo os melhores resultados verificados no sistema intensivo de criação.

- Nas interações significativas entre linhagem e sistema de criação, as linhagens de crescimento lento no sistema semi-intensivo de criação apresentaram maiores idades 2300, menores GPMD em relação as linhagens de crescimento rápido, entretanto mostraram-se mais eficientes na produção de carne de peito.

- As interações significativas encontradas entre linhagem e sistema de criação indicaram que no sistema semi-intensivo as linhagens de crescimento lento tiveram uma tendência de redução da taxa de crescimento, em relação ao sistema intensivo, enquanto não se verificou essa tendência nas linhagens de crescimento rápido. 
- O rendimento de carne de peito teve uma tendência de aumento nas linhagens de crescimento lento no sistema semi-intensivo e de redução nas linhagens de crescimento rápido. 


\section{REFERÊNCIAS BIBLIOGRÁFICAS}

ABREU, V.M.N.; SILVA, M.A.; SOARES, P.R.; TORRES, R.A.; FERREIRA, V.Q.; ABREU, P.G. Efeitos dos níveis de energia da ração e de cruzamentos sobre o peso e rendimento da carcaça e partes e deposição de gordura abdominal de frangos de corte. Revista da Sociedade Brasileira de Zootecnia, v. 25, n. 2, p. 223-232, 1996a.

ABREU, V.M.N.; SILVA, M.A.; SOARES, P.R.; TORRES, R.A.; FERREIRA, V.Q.; ABREU, P.G. Efeitos dos níveis de energia da ração e de cruzamentos sobre a composição da carcaça de frangos de linha de corte. Revista da Sociedade Brasileira de Zootecnia, v. 25, n. 2, p. 233-239, 1996 b.

ABREU, V.M.N.; SILVA, M.A.; TORRES, R.A.; SOARES, P.R.; PANIAGO, M.T.; ABREU, P.G. Características produtivas de linhagens de corte. Revista da Sociedade Brasileira de Zootecnia, v. 25, n. 1, p. 83-91, 1996c.

ACAR, N.; MORAN Jr, E.T.; BILGILI, S.F. Live performance and carcass yield of male broilers from two commercial strain crosses receiving ratinos containing lysine blow and above the established requirement between six and weeks of age. Poultry Science, 70(11): 2315-21, 1991.

ALMEIDA, I.C.L.; MENDES, A.A.; GARCIA, R.G.; TAKITA, T.S.; MOREIRA, J.; GARCIA, E.A. Efeito do nível de lisina da dieta e do sexo sobre o desempenho e rendimento de carcaça de frangos de corte. Revista Brasileira de Ciência Avícola, v. 4, n1, p. 11-18, 2002. 
AVILA, V.S.; LEDUR, M.C.; BARIONI JUNIOR, W.; SCHMIDT, G.S.; COSTA, C.N. Desempenho e qualidade de carcaça em linhagens comerciais de frangos de corte. Pesquisa Agropecuária Brasileira, v. 28, n. 6, p. 649-656, 1993.

BERTECHINI, A.G.; ROSTAGNO, H.S.; SILVA, M.A.; OLIVEIRA, A.I.G. E. Efeitos da temperatura ambiente e nível de energia sobre o desempenho e a carcaça de frangos de corte. Revista da Sociedade Brasileira de Zootecnia, v.20, n. 3, p. 218228, 1991.

BOLIS, D.A. Biosseguridade na criação alternativa de frangos. In: CONFERÊNCIA DE CIÊNCIA E TECNOLOGIA AVÍCOLA - APINCO, Campinas, 2001. Anais. Campinas, Apinco: 2001. p. 223 - 234.

BOWMAN, J.C. Introdução ao melhoramento animal. São Paulo. EPU-USP, 1981.

CARRIJO, A.S.; MENEZES, G.P.; SILVA, M.J.; OLIVEIRA, M.S.S.; ONSELEN, V. J. Avaliação de linhagens alternativas na criação de frangos tipo caipira. In: CONFERÊNCIA DE CIÊNCIA E TECNOLOGIA AVÍCOLA - APINCO, Campinas, 2002. Anais. Campinas: Apinco, 2002. p. 84.

CIOCCA, M.L; CARDOSO, S.; FRANZOSI, R. Criação de galinhas em sistemas semi-intensivos. Porto Alegre: Pallotti, 199. 112p.

FERNANDES, L.M.; VIEIRA, S.L.; BAPTISTA, C.B. Desenvolvimento da órgãos da digestão e rendimento de carcaça de frangos de corte de diversas origens genéticas criados com bebedouros pendular e nipple. Revista Brasileira de Ciência Avícola, v. 4, n1, p. 73-84, 2002. 
FIGUEIREDO, E.A.P. Diferentes denominações e classificação brasileira de produção alternativa de frangos. In: CONFERÊNCIA DE CIÊNCIA E TECNOLOGIA AVÍCOLA - APINCO, Campinas, 2001. Anais. Campinas: Apinco, 2001. p. 209 222.

FIGUEIREDO, E.A.P.; ROSA, O.S.; OMM, E.R.; BOFF, J.A, BASSI, L. Peso e tamanho de órgãos de diferentes linhagens de frango de corte. In: CONFERÊNCIA DE CIÊNCIA E TECNOLOGIA AVÍCOLA - APINCO, Campinas, 2002. Anais. Campinas: Apinco, 2002. p. 95.

GARCIA, E.A.; SILVA, A.B.P. Desempenho e rendimento de carcaça de três linhas comerciais de frangos de corte. In: CONFERÊNCIA DE CIÊNCIA E TECNOLOGIA AVÍCOLA - APINCO, Campinas, 1989. Anais. Campinas: Apinco, 1989. p. 157.

GARCIA, E.A.; MENDES, A.A.; CURI, P. R.; SILVA, A.B.P.; DIERCKX, S.M.A.G. Desempenho rendimento de carcaça de três linhagens comerciais de frangos de corte. Veterinária e Zootecnia, v. 3, p. 1-8, 1991.

GARCIA, E.A.; MENDES, A.A.; SILVA, A.B.P.; GONZALES, E. Efeito da linhagem e da ração sobre o desempenho de frangos de corte e rendimento de carcaça. Veterinária e Zootecnia, v. 4, p. 7-15, 1992.

GARCIA, E.A.; MENDES, A.A.; CURI, P. R.; SILVA, A.B.P.; GONZALES, E. Efeito do nível de energia da dieta e do sexo sobre o rendimento de carcaça de frangos de corte. Veterinária e Zootecnia, v. 5, p. 29-37, 1993.

GARCIA, E.A.; MENDES, A.A.; CURI, P. R.; SILVA, A.B.P.; GONZALES, E. Efeito do nível de energia da dieta e do sexo sobre o rendimento de carcaça de frangos de corte. Veterinária e Zootecnia, v. 5, p. 5-29, 1996. 
GESSULLI, O.P. Avicultura alternativa: sistema "ecologicamente coreto" que busca o bem estar animal e a qualidade do produto final. Porto Feliz: OPG Editores, 1999. $217 \mathrm{p}$.

LANA, G.R.Q.; ROSTAGNO, H.S.; ALBINO, L.F.T.; LANA, A.M.Q. Efeito da temperatura ambiente e da restrição alimentar sobre o desempenho e a composição da carcaça de frangos de corte. Revista da Sociedade Brasileira de Zootecnia, v. 29, n. 4, p. 1117-1123, 2000.

LEANDRO, N.S.M.; ROCHA, P.T.; SHAITL, M.; STRINGHINI, J.H.; FORTES, R.M. Efeito do tipo de captura dos frangos de corte sobre a qualidade da carcaça. gordura In: REUNIÃO ANUAL DA SOCIEDADE BRASILEIRA DE ZOOTECNIA, $38^{\mathrm{a}}$, Piracicaba, 2001. Anais. Piracicaba: SBZ, 2001. p. 384-385.

LISBOA, J.S. Desempenho de três grupos genéticos de frangos de corte produzidos na UFV, submetidos a rações com diferentes teores de proteína. Viçosa, 1995. Dissertação (Mestrado) - Universidade Federal de Viçosa.

LEU, W.M.K. Desempenho e rendimento de carcaça de frangos submetidos a restrição alimentar na fase inicial, em diferentes sistemas de criação. Lavras, 2000. Dissertação (Mestrado) - Universidade Federal de Lavras.

MIZUBUTI, I.Y.; FONSECA, N.A.N.; PINHEIRO, J.W. Desempenho de duas linhagens comerciais de frangos de corte, criadas sob diferentes densidades populacionais e diferentes tipos de cama. Revista da Sociedade Brasileira de Zootecnia, v.23, n. 3, p. 476-484, 1994. 
MENDES, A.A. Carcaça, como medir o rendimento. Avicultura \& Suinocultura, 955: 86-89, 1989.

MENDES, A.A. Efeito de fatores genéticos, nutricionais e de ambiente sobre o rendimento de carcaça de frangos de corte. Botucatu, 1990. 103p. Tese (Livre Docência). Faculdade de Medicina Veterinária e Zootecnia, Universidade Estadual Paulista.

MENDES, A.A.; GARCIA, E.A.; GONZALE, E.; SILVA, A.B.P. Efeito do peso de abate sobre o rendimento de carcaça de frangos de corte. Veterinária e Zootecnia, v. 5, p. 77-82, 1993a.

MENDES, A.A.; GARCIA, E.A.; GONZALES, E.; VAROLI, J.C. Efeito da linhagem e idade de abate sobre rendimento de carcaça de frangos de corte. Revista da Sociedade Brasileira de Zootecnia, v.22, n. 3, p. 467-471, 1993 b.

MENDES, A.A.; GONZALES, E.; GARCIA, E.A.; MORITA, M. Efeitos do nível nutricional da dieta e do sexo sobre o rendimento de carcaça de frangos de corte. Revista da Sociedade Brasileira de Zootecnia, v.22, n. 3, p. 473-480, 1993c.

MENDES, A.A.; GARCIA, E.A.; SILVA, A.B.P. Efeito do cruzamento de linhagens sobre o rendimento de carcaça de frangos de corte. Veterinária e Zootecnia, v. 6, p. 57-63, 1994.

MENDES, A.A.; POLITI, E.S.; GARCIA, E.A.; SARTORI, J.R. Efeito da utilização de rações fareladas e peletizadas sobre o desempenho e rendimento de carcaça de frangos de corte. Veterinária e Zootecnia, v. 7, p. 31-40, 1995. 
MIZUBUTI, I.Y.; FONSECA, N.A.N.; PINHEIRO, J.W. Desempenho de duas linhagens comerciais de frangos de corte, criadas sob diferentes densidades populacionais e diferentes tipos de cama. Revista da Sociedade Brasileira de Zootecnia, v. 23, n. 3, p. 477-484, 1994.

MOREIRA, J.; MENDES, A.A.; GARCIA, E.A.; GARCIA, G.R.; ALMEIDA, I.C.L.; JUNIOR, J.G.C. Efeito do uso de probiótico sobre o desempenho e rendimento de carcaça em frangos de corte In: REUNIÃO ANUAL DA SOCIEDADE BRASILEIRA DE ZOOTECNIA, 38 a ., Piracicaba, 2001. Anais. Piracicaba: SBZ, 2001. p. 852-854.

MURAKAMI, A.E.; CAMPOS, E.J.; BAIÃO, E.C. Rendimento da carcaça e partes da carcaça de frangos de corte. In: CONGRESSO BRASILEIRO DE AVICULTURA, 8, Camburiú, 1983. Anais. Camburiú: UBA, 1983. p. 601-611.

NAAS, I.A. Produção avícola e meio ambiente. In: CONFERÊNCIA DE CIÊNCIA E TECNOLOGIA AVÍCOLA - APINCO, Campinas, 2001. Anais. Campinas: Apinco, 2001. p. $273-283$.

OLIVEIRA NETO, A.R.; OLIVEIRA, R.F.M.; DONZELE, J.L.; ROSTAGNO, H.S.; FERREIRA, R. A; MAXIMIANO, H. C.; GASPARINO. E. Efeito da temperatura ambiente sobre o desempenho e características de carcaça de frangos de corte alimentados com dieta controlada e dois níveis de energia metabolizável. Revista da Sociedade Brasileira de Zootecnia, v.29, n. 1, p. 183-190, 2000.

PEZZATO, L.E.; MENDES, A.A.; DE SOUZA, J.L.G.; GARCIA, E.A.; MEIRA, A.S.

A. Rendimento de carcaça de frango de corte. I. Efeito da linhagem e sexo. In: CONGRESSO BRASILEIRO DE AVICULTURA, 7, Recife, 1981. Anais. Recife: UBA, 1981. p. 149-156. 
POLITI, E.S.;VAROLI JR, J.C.; GONSALES, E.; POIATTI, M.L A. Efeito da linhagem e sexo sobre o desempenho e rendimento de carcaça de frangos de corte. In: CONFERÊNCIA DE CIÊNCIA E TECNOLOGIA AVÍCOLA - APINCO, Santos, 1993. Anais. Santos: Apinco, 1993. p. 88.

POLITI, E.S.; MENDES, A.A.; VAROLI Jr, J.C.; GONSALES, E.; GARCIA, E. A. Efeito da linhagem e sexo sobre o desempenho e rendimento de carcaça de frangos de corte. Veterinária e Zootecnia, v. 6, p. 187-195, 1994.

REIS, J.C.; LÔBO, R.B. Interações genótipo ambiente nos animais domésticos. Ribeirão Preto: J.C.R./R.B.L., 1991. 182p.

RIBEIRO, D.F. Fatores de manejo que afetam o rendimento e a qualidade de carcaça de frango de corte. In: CONFERÊNCIA DE CIÊNCIA E TECNOLOGIA AVÍCOLA APINCO, Campinas, 1989. Anais. Campinas: Apinco, 1989. p.23-32..

ROSA, A.P.; BRITTES, L.B.P.; FERREIRA, J.E.; KRACKER, J.; DILKIN, P.; MEDEIROS, L.A.M. Análise de carcaça de frangos de corte Arbor acres, Pilch e seus cruzamentos. In: CONFERÊNCIA DE CIÊNCIA E TECNOLOGIA AVÍCOLA APINCO, Santos, 1993. Anais. Santos: Apinco, 1993. p. 95.

ROSTAGNO, H.S.; BARBARINO Jr, P.; BARBOSA, W.A. Exigências nutricionais das aves determinadas no Brasil. In: SIMPÓSIO INTERNACIONAL SOBRE EXIGÊNCIAS NUTRICIONAIS DE AVES E SUÍNOS, Viçosa, 1996. Anais. Viçosa: UVF, 1996. p. 361-388.

SCHMIDT, G.S.; CUSTÓDIO, R.W.S. Características de carcaça em populações e híbridos de frangos de corte. ARS Veterinária, v.14, n. 1, p. 93-100, 1998. 
SILVA, M.A.N. Seleção de linhagens de galinhas para corte adaptadas ao sistema de criação semi-intensivo. Piracicaba, 2001. Dissertação (Mestrado) - Escola Superior de Agricultura Luiz de Queiroz.

SILVA, R.D.M.; NAKANO, M. Sistema caipira de criação de galinhas. Piracicaba: O Editor, 1998. 110p.

SILVEIRA, M.H.D.; COSTA, P.T.C. Efeito das inhas sobre rendimemnto de cacaça e cortes nobres de frango de corte. In: CONFERÊNCIA DE CIÊNCIA E TECNOLOGIA AVÍCOLA - APINCO, Campinas, 1990. Anais. Campinas: Apinco, 1990. p. 179-180.

SOUZA, P.A.; SOUZA, H.B.A.; CAMPOS, F.P.; BROGNONI, E.; OKADA, E.T. Desempenho e características de carcaça de diferentes linhagens comerciais de frangos de corte. In: CONFERÊNCIA DE CIÊNCIA E TECNOLOGIA AVÍCOLA APINCO, Santos, 1993. Anais. Santos: Apinco, 1993. p. 84.

SOUZA, P.A.; SOUZA, H.B.A.; CAMPOS, F.P.; BROGNONI, E. Desempenho e características de carcaça de diferentes linhagens comerciais de frangos de corte. Revista da Sociedade Brasileira de Zootecnia, v. 23, n. 5, p. 782-791, 1994.

SUGETA, M.S.; BRUNO, L.D.G.; DAHLKE, F.; ALMEIDA, J.G.; FARIA FILHO, D. E.; FURLAN, R.L.; MACARI, M. Avaliação do desempenho produtivo, deposição de gordura In: REUNIÃO ANUAL DA SOCIEDADE BRASILEIRA DE ZOOTECNIA, 38., Piracicaba, 2001. Anais. Piracicaba: SBZ, 2001. p. 1173-1174. 
VIANA, C.F.A.; SILVA, M.A.; PIRES, A.V.; FONSECA, R.; SOARES, P.R. Influência de grupos genéticos e de níveis de energia sobre características de carcaça de frangos de corte. Revista Brasileira de Zootecnia, v. 29, n. 4, p. 1067-1073, 2000.

WHITAKER, H.M.A.; MENDES, A.A.; GARCIA, E.A.; ROÇA, R.O.; VAROLLI Jr, J.C.; SALDANHA, E.P.B. Efeito da suplementação de metionina sobre o desempenho e a avaliação de carcaça de frangos de corte. Revista Brasileira de Ciência Avícola, v. 4, n1, p. 63-71, 2002. 